\title{
Measurements of iodine monoxide at a semi polluted coastal location
}

\author{
K. L. Furneaux ${ }^{1, \dagger}$, L. K. Whalley ${ }^{1,5}$, D. E. Heard ${ }^{1}$, H. M. Atkinson ${ }^{1 *}$, W. J. Bloss ${ }^{1 * *}$, M. J. Flynn ${ }^{2}$, M. W. Gallagher ${ }^{2}$, \\ T. Ingham ${ }^{1,5}$, L. Kramer ${ }^{3 * * *}$, J. D. Lee ${ }^{4,6}$, R. Leigh ${ }^{3}$, G. B. McFiggans ${ }^{2}$, A. S. Mahajan ${ }^{1}$, P. S. Monks ${ }^{3}$, H. Oetjen ${ }^{1}$, \\ J. M. C. Plane ${ }^{1}$, and J. D. Whitehead ${ }^{2}$ \\ ${ }^{1}$ School of Chemistry, University of Leeds, Woodhouse Lane, Leeds, LS2 9JT, UK \\ ${ }^{2}$ Centre for Atmospheric Sciences, School of Earth, Atmospheric Environmental Sciences, University of Manchester, \\ Manchester, M13 9PL, UK \\ ${ }^{3}$ Earth Observation Science, Space Research Centre, Department of Physics and Astronomy, University of Leicester, \\ University Road, Leicester LE1 7RH, UK \\ ${ }^{4}$ Department of Chemistry, University of York, Heslington, York, YO10 5DD, UK \\ ${ }^{5}$ National Centre for Atmospheric Sciences, University of Leeds, Leeds, LS2 9JT, UK \\ ${ }^{6}$ National Centre for Atmospheric Sciences, University of York, Heslington, York, YO10 5DD, UK \\ *now at: British Antarctic Survey, Madingley Road, Cambridge, CB3 OET, UK \\ ** now at: School of Geography, Earth Environmental Sciences, University of Birmingham, Edgbaston, Birmingham, \\ B15 2TT, UK \\ *** now at: Departments of Geological and Mining Engineering and Sciences and Civil \& Environmental Engineering, \\ Michigan, Technological University, 1400 Townsend Dr., Houghton, MI 49931, USA \\ ${ }^{\dagger}$ sadly passed away 28 July 2009
}

Received: 27 October 2009 - Published in Atmos. Chem. Phys. Discuss.: 1 December 2009

Revised: 2 March 2010 - Accepted: 7 April 2010 - Published: 20 April 2010

\begin{abstract}
Point source measurements of IO by laser induced fluorescence spectroscopy were made at a semi-polluted coastal location during the Reactive Halogens in the Marine Boundary Layer (RHaMBLe) campaign in September 2006. The site, on the NW French coast in Roscoff, was characterised by extensive intertidal macroalgae beds which were exposed at low tide. The closest known iodine active macroalgae beds were at least $300 \mathrm{~m}$ from the measurement point. From 20 days of measurements, IO was observed above the instrument limit of detection on 14 days, of which a clear diurnal profile was observed on 11 days. The maximum IO mixing ratio was $30.0 \mathrm{pptv}$ (10 s integration period) during the day, amongst the highest concentrations ever observed in the atmosphere, and 1-2 pptv during the night. IO concentrations were strongly dependent on tidal height, the intensity of solar irradiation and meteorological conditions. An intercomparison of IO measurements made using point source and spatially averaged DOAS in-
\end{abstract}

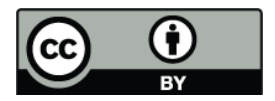

Correspondence to: D. E. Heard (d.e.heard@leeds.ac.uk) struments confirms the presence of hot-spots of IO caused by an inhomogeneous distribution of macroalgae. The coincident, point source measurement of IO and ultra fine particles $(2.5 \mathrm{~nm} \geq d \geq 10 \mathrm{~nm})$ displayed a strong correlation, providing evidence that IO is involved in the production pathway of ultra fine particles at coastal locations. Finally, a modelling study shows that high IO concentrations which are likely to be produced in a macrolagae rich environment can significantly perturb the concentrations of $\mathrm{OH}$ and $\mathrm{HO}_{2}$ radicals. The effect of $\mathrm{IO}$ on $\mathrm{HO}_{\mathrm{x}}$ is reduced as $\mathrm{NO}_{\mathrm{x}}$ concentrations increase.

\section{Introduction}

The IO radical can impact several important atmospheric chemistry processes through its reaction pathways and cycles. These include partitioning of $\mathrm{HO}_{\mathrm{x}}$ and $\mathrm{NO}_{\mathrm{x}}(\mathrm{McFig}-$ gans et al., 2000; Platt and Hönninger, 2003; Bloss et al., 2005), ozone depletion (Davis et al., 1996; Read et al., 2008), formation and growth of new particles (Hoffmann et al.,

Published by Copernicus Publications on behalf of the European Geosciences Union. 
2001; O'Dowd et al., 2002; McFiggans et al., 2004) and liberation of halogens from sea salt (Vogt et al., 1996; McFiggans et al., 2002).

Iodine species are present at coastal and open ocean regions due to the release of $\mathrm{I}_{2}$ and halocarbons from macroalgae and microalgae. The daytime IO source is photolysis of these molecules to yield iodine atoms, which react with ozone to produce IO (Reactions R1 and R2). The subsequent photolysis of IO results in a steady-state between IO and I. If IO reacts with itself, $\mathrm{BrO}, \mathrm{HO}_{2}$ or $\mathrm{NO}_{2}, \mathrm{O}_{3}$ destruction can occur (e.g. Mahajan et al., 2009a for the field site presented in this paper). The night-time source of IO is proposed to be the reaction of $\mathrm{I}_{2}$ with $\mathrm{NO}_{3}$ (Reaction $\mathrm{R} 3$ ) followed by the subsequent reaction of I with $\mathrm{O}_{3}$, (Chambers et al., 1992). Recent modelling calculations confirm that this is the likely pathway to night-time IO (Kaltsoyannis and Plane, 2008).

$\mathrm{I}_{2}+\mathrm{h} v \rightarrow 2 \mathrm{I}$

$\mathrm{I}+\mathrm{O}_{3} \rightarrow \mathrm{IO}+\mathrm{O}_{2}$

$\mathrm{I}_{2}+\mathrm{NO}_{3} \rightarrow \mathrm{I}+\mathrm{INO}_{3}$

Halogen activity has been observed at many mid-latitude coastal locations including Mace Head (Ireland) (Alicke et al., 1999; Allan et al., 2000; Saiz-Lopez and Plane, 2004), Brittany (NW France), the North Sea coast (Germany) (Peters et al., 2005), Appledore Island (USA) (Stutz et al., 2007), Tenerife (Canary Islands) (Allan et al., 2000) and Cape Grim (Australia) (Allan et al., 2000; Cainey et al., 2007). Mace Head provides the only positive observation of night-time IO to date (Saiz-Lopez and Plane, 2004). These sites provide a mixture of $I$ atom sources dominated by either $I_{2}$ or iodocarbons. The measurements presented in this paper were made at Roscoff, a coastal site on the NW coast of France, as part of the Reactive Halogens in the Marine Boundary Layer (RHaMBLe) programme. RHaMBLe aimed to quantify the impacts of marine halogen emissions on atmospheric composition. An overview of the RHaMBLe programme, including its motivations and objectives, is provided by McFiggans et al. (2010).

The RHaMBLe-Roscoff campaign was unique because it provided a comparison of a variety of point source and spatially averaged detection methods in a semi-polluted environment. The majority of IO observations have taken place in low $\mathrm{NO}_{\mathrm{x}}$ environments (West Ireland, Tenerife, NW France, Cape Grim, Antarctica and the Arctic) with the exception of the daytime detection of IO at Appledore Island, Gulf of Maine, when 1-4 pptv of IO was detected in the presence of 5-10 ppbv of $\mathrm{NO}_{2}$ (Stutz et al., 2007). This paper presents comparisons of IO measurements with different spatial footprints and simultaneous point source IO and particle measurements. Previously, the majority of IO measurements have used long-path differential optical absorption spectroscopy (LP-DOAS), which provides an average IO concentration over several kilometers of the light path. The use of laser induced fluorescence spectroscopy (LIF) provides a point source measurement at time resolutions as short as one second. Combined with measurements from instruments such as LP-DOAS, a greater understanding of the spatial distribution of IO is possible. As chemistry models are normally constrained by point source measurements (e.g. $\mathrm{O}_{3}$, $\mathrm{NO}, \mathrm{NO}_{2}$ and photolysis frequencies), LIF IO measurements can provide a more appropriate model constraint. It is often necessary to interpret field data and the associated theoretical implications through the use of hot-spot emissions of $\mathrm{I}_{2}$ due to concentrated emissions from macroalgae beds, rather than homogeneous emissions over a wider area (Pechtl et al., 2006; Kanaya et al., 2002; Sommariva et al., 2006; SaizLopez et al., 2006). The field observations from Roscoff aim to address and validate this approach.

The formation of new particles in coastal environments via a mechanism involving iodine oxides has not been categorically proven, despite laboratory efforts and a number of field studies (Cox et al., 1999; Hoffmann et al., 2001; O'Dowd et al., 2002; Makela et al., 2002; Jimenez et al., 2003; McFiggans et al., 2004; Burkholder et al., 2004; Palmer et al., 2005; Sellegri et al., 2005; Pirjola et al., 2005; Saiz-Lopez et al., 2006). Laboratory studies and theoretical calculations show that $\mathrm{I}_{2} \mathrm{O}_{3}$ and $\mathrm{I}_{2} \mathrm{O}_{5}$ are the most likely iodine oxide species to form new particles at ambient conditions, which appear to be composed of $\mathrm{I}_{2} \mathrm{O}_{5}$ (Saunders and Plane, 2005; Kaltsoyannis and Plane, 2008), although uptake of $\mathrm{HIO}_{3}$ from the gas phase onto pre-existing aerosols has also been proposed (Pechtl et al., 2007). In open ocean regions new particle formation occurs via sulphur containing species but in coastal regions an additional nucleating component has been postulated to be required (O'Dowd et al., 1999; Kulmala et al., 2000). The following reaction scheme is suggested to lead to new particle formation (Reactions R4-R9; Hoffmann et al., 2001; Jimenez et al., 2003; Burkholder et al., 2004; Saunders and Plane, 2005; Kaltsoyannis and Plane, 2008).

$$
\begin{aligned}
& \mathrm{IO}+\mathrm{IO} \rightarrow \mathrm{I}_{2} \mathrm{O}_{2} \\
& \mathrm{I}_{2} \mathrm{O}_{2}+\mathrm{O}_{3} \rightarrow \mathrm{I}_{2} \mathrm{O}_{3}+\mathrm{O}_{2} \\
& \mathrm{IO}+\mathrm{OIO} \rightarrow \mathrm{I}_{2} \mathrm{O}_{3} \\
& \mathrm{I}_{2} \mathrm{O}_{3}+\mathrm{O}_{3} \rightarrow \mathrm{I}_{2} \mathrm{O}_{4}+\mathrm{O}_{2} \\
& \mathrm{OIO}+\mathrm{OIO} \rightarrow \mathrm{I}_{2} \mathrm{O}_{4} \\
& \mathrm{I}_{2} \mathrm{O}_{4}+\mathrm{O}_{3} \rightarrow \mathrm{I}_{2} \mathrm{O}_{5}+\mathrm{O}_{2}
\end{aligned}
$$

Field observations of iodine species within aerosols and precipitation, however, have found low levels of iodate compared to iodide and soluble organically bound iodine, which may be inconsistent with this production pathway and introduces some uncertainty (Gilfedder et al., 2008). Additionally, experimental work has provided evidence for the photolysis of OIO to form exclusively $\mathrm{I}+\mathrm{O}_{2}$ (Gomez Martin et al., 
2009), which could compromise the proposed reaction pathway. Most recently, Mahajan et al. (2009b) have suggested that particle formation at coastal sites may only occur via a sub-section of the above Reactions (R4), (R6) and (R8) with the $\mathrm{I}_{2} \mathrm{O}_{4}$ formed acting as a nucleant and the $\mathrm{I}_{2} \mathrm{O}_{3}$ condensing on to any existing $\mathrm{I}_{2} \mathrm{O}_{4}$ clusters. Despite uncertainties associated with the formation of new particles, coordinated observations provide strong evidence that new particle formation in coastal locations occurs via a mechanism involving iodine oxides.

Field measurements at Mace Head during the NAMBLEX campaign were the first coordinated measurements of in situ $\mathrm{I}_{2}$ and ultra-fine particles (diameter $<10 \mathrm{~nm}$ ) (Heard et al., 2006). In combination with a modelling study, these measurements provided further evidence that $\mathrm{I}_{2}$ is a necessary precursor to particle events (Saiz-Lopez et al., 2006). The measurements presented here from Roscoff provide the coordinated measurements of in situ IO and ultra-fine particles, providing further evidence of the role of IO in particle formation pathways.

The Leeds LIF IO instrument was deployed for the first time during the RHaMBLe-Roscoff campaign, providing the first measurements of ambient IO by LIF (Whalley et al., 2007). A range of other instruments were deployed during this campaign, providing gas and aerosol measurements, as described by McFiggans et al. (2010). This paper presents measurements of IO from the RHaMBLe-Roscoff field campaign. Section 2 describes the field site and instrumentation. Section 3 presents point source measurements of IO, including a discussion of the influences on IO chemistry at the field site, a comparison of IO measurements by point source and spatially averaged instruments, followed by a discussion of the link between IO and new particle formation. Section 4 discusses the impact of $\mathrm{IO}$ on daytime $\mathrm{OH}$ and $\mathrm{HO}_{2}$.

\section{Methods and instrumentation}

\subsection{The field site at Roscoff}

Field observations were made at Roscoff, a small town on the NW Atlantic coast of France $\left(48.726^{\circ} \mathrm{N}, 3.988^{\circ} \mathrm{W}\right)$ during September 2006 (McFiggans et al., 2010). The seabeds surrounding Roscoff have a dense coverage of intertidal macroalgae, including inhomogeneously distributed beds of Laminaria and Ascophyllum which are exposed at low tide (Fig. 1). The macroalgae speciation at Roscoff indicates that the closest macroalgae beds that strongly emit iodine compounds were $300 \mathrm{~m}$ from the LIF instrument. Further details on the macroalgae distribution at Roscoff can be found in Leigh et al. (2009). During the campaign the tidal range was near its annual maximum (the maximum tidal range during the campaign was $9.25 \mathrm{~m}$ ).

The measurement site was located directly on the Roscoff sea front (Fig. 2). During the campaign air masses were pre-

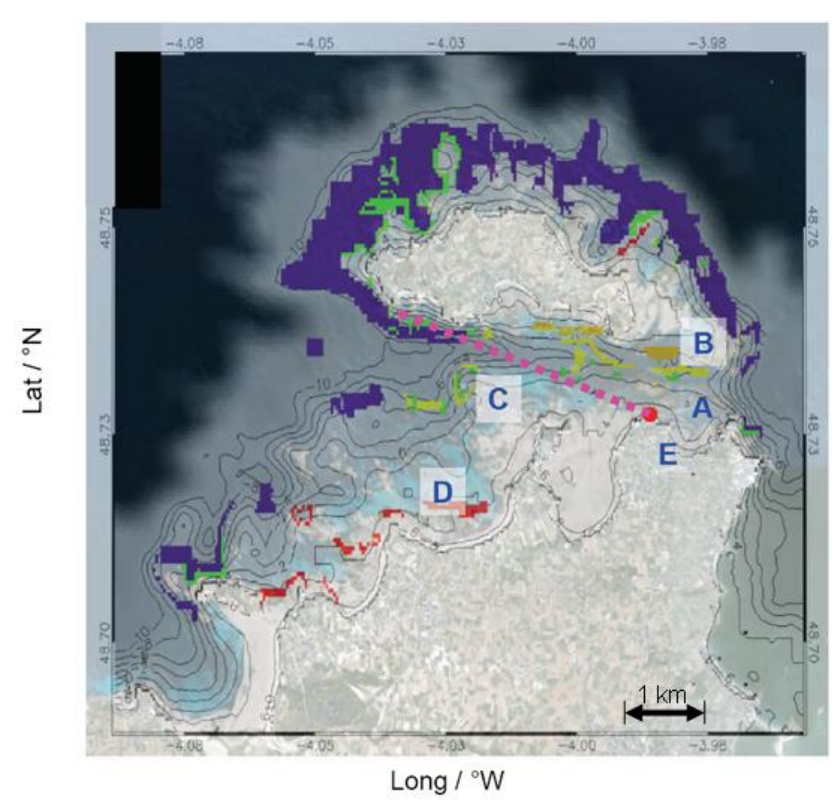

Fig. 1. Map of macroalgae for the Roscoff area. Known emitters of iodine species are Laminaria digitata (green), Laminaria hyperborea (purple), Laminaria ochroleuca (yellow), Laminaria saccharina (orange) and Ascophyllum/Fucus (red). The red dot marks the location of the LIF instrument. The dashed pink line represents the LP-DOAS light path. Letters refer to macroalgae areas referred to in the text.

dominantly north Atlantic in origin. $\mathrm{NO}_{\mathrm{x}}$ levels $\left(\mathrm{NO}+\mathrm{NO}_{2}\right)$ were high throughout the campaign (approximately 1$5 \mathrm{ppbv}$ ), due to the proximity of the measurement site to the town (the site was adjacent to a minor road). There was one day of clean air with $\mathrm{NO}_{\mathrm{x}}$ less than 1 ppbv.

\subsection{Instrumentation}

This paper presents measurements of IO by LIF, details of other measurements during the campaign can be found in McFiggans et al. (2010) and references therein. A full description of the instrument can be found in Whalley et al. (2007). In brief, ambient air is sampled through a conical nozzle with a pinhole diameter of $0.8 \mathrm{~mm}$ (flow rate $=5 \mathrm{slm}$ ) into a LIF cell held at 150 Torr. The $(2,0)$ band of the IO $A^{2} \Pi_{3 / 2} \leftarrow X^{2} \Pi_{3 / 2}$ electronic transition at approximately $445 \mathrm{~nm}$ (an all solid-state Nd:YAG pumped Ti:Sapphire laser was used to generate radiation at $890 \mathrm{~nm}$ and this was frequency doubled to produce the desired wavelength) is used to electronically excite the IO radical, with off-resonance fluorescence detection of the $(2,5)$ band at $521 \mathrm{~nm}$. Laser scattered light is filtered out using a $520.3 \mathrm{~nm}$ centred bandpass filter. Fluorescence is collected using a channeltron photomultiplier (CPM), with the signal recorded by a computer controlled gated photon counter. The instrument collection cycle was either $50 \mathrm{~s}$ or $150 \mathrm{~s}$ on-resonance collection, 


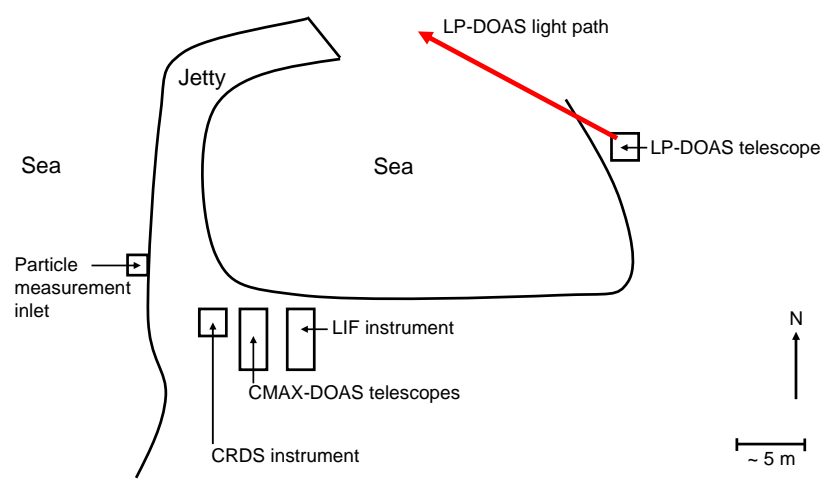

Fig. 2. A schematic of the Roscoff measurement site at high tide. Highlighted instrumentation includes LIF, LP-DOAS, Concurrent Multi Axis DOAS (CMAS-DOAS), Cavity Ringdown Spectroscopy (CRDS) and particle number and size-distribution measurements.

followed by a temporally identical off-line collection period to measure the background signal. Data were collected at $10 \mathrm{~s}$ intervals and scattered solar light was subtracted for each data point. The laser wavelength was determined by a wavemeter, with the off-line position $0.004-0.006 \mathrm{~nm}$ below the IO excitation wavelength (online wavelength position was $444.887 \mathrm{~nm}$ and offline position was typically $444.882 \mathrm{~nm})$.

Daily calibrations were performed throughout the campaign to determine the sensitivity of the IO LIF instrument. Photolysis at $184.9 \mathrm{~nm}$ (generated using a $\mathrm{Hg}$ lamp) of $\mathrm{N}_{2} \mathrm{O} / \mathrm{CF}_{3} \mathrm{I} / \mathrm{N}_{2}$ mixtures was used to generate IO between 10 to $150 \mathrm{pptv}$. Ozone actinometry was used to determine the lamp flux, allowing calculation of the concentrations of IO produced. Potential interferences due to $\mathrm{NO}_{2}$ fluorescence or laser generated IO were ruled out by laboratory experiments (Whalley et al., 2007). The accuracy of the measurement is equal to $23 \%(1 \sigma)$. The uncertainties in the absolute IO concentration generated during calibration arise from uncertainties associated with the chemical yield of IO from the reaction $\mathrm{O}\left({ }^{3} \mathrm{P}\right)$ with $\mathrm{CF}_{3} \mathrm{I}$, the lamp flux determination (from ozone actinometry), the concentration of $\mathrm{N}_{2} \mathrm{O}$ present and estimates of the chemical loss of IO between point of generation and LIF sampling. Other uncertainties relate to the laser power measurement and the variability in the absorption cross-section of the IO bandhead at the laser spectral bandwidth for the wavelength precision $( \pm 0.001 \mathrm{~nm})$ achievable by the wavemeter used to control the laser wavelength (Whalley et al., 2007). The signal variation observed at a constant $[\mathrm{IO}]$ (equal to $\sim 5 \%$ ) represents the random error associated with the instrument precision.

The instrument is capable of providing a high temporal resolution. Throughout the campaign, the minimum online collection period was $10 \mathrm{~s}$. The sensitivity of the instrument decreased gradually throughout the campaign due to degra- dation of the CPM response, which resulted in the limit of detection of the instrument increasing by a factor of ten over the campaign. When the instrument was performing at its best the limit of detection was $0.4 \mathrm{pptv}$ over a $150 \mathrm{~s}$ integration period (determined using the following equations):

$\mathrm{LOD}=\frac{\mathrm{SNR}}{\mathrm{C}_{\mathrm{IO}} \times \mathrm{P}} \sqrt{\frac{1}{m}+\frac{1}{n}} \cdot \sigma_{b}$

where SNR is the signal to noise ratio, $\mathrm{C}_{\mathrm{IO}}$ is the sensitivity of the instrument (counts $\mathrm{s}^{-1} \mathrm{~mW}^{-1}$ molecule $\mathrm{e}^{-1} \mathrm{~cm}^{3}$ ), $P$ is the laser power $(\mathrm{mW}), m$ is the number of IO on-resonance (online) data points, $n$ is the number of background (offline) data points and $\sigma_{b}$ is the sample standard deviation of the background signal (counts $\mathrm{s}^{-1}$ ). The sample standard deviation of the background signal is defined as:

$\sigma_{b}=\sqrt{\frac{1}{t} S_{l b}+S_{s b}+S_{d b}}$

where $t$ is the averaging time of each data point $(s), S_{l b}$ is the laser background signal (counts s ${ }^{-1}$ ), $S_{s b}$ is the signal due to solar counts (counts $\mathrm{s}^{-1}$ ) and $S_{d b}$ is the signal due to CPM dark counts (counts s ${ }^{-1}$ ).

The LIF IO instrument was located in a shipping container adjacent to the seawall and a small jetty at the edge of the town (Fig. 2). The LIF cell was located on the roof of the shipping container with the inlet pinhole at a height of $3.5 \mathrm{~m}$ above ground level. At high tide the LIF cell was approximately $3.5 \mathrm{~m}$ horizontally displaced from the water.

Measurements of $\mathrm{NO}$ and $\mathrm{NO}_{2}$ were made simultaneously from an inlet located on the CMAX-DOAS mast on the Leicester container at a height of $3.5 \mathrm{~m}$ using two chemiluminescence $\mathrm{NO}$ detectors (Ecophysics CLD780TR); $\mathrm{NO}_{2}$ was detected as NO after photolytic conversion.

Measurements of particle number concentration were made using Condensation Particle Counters (TSI models UCPC $3776(2.5 \mathrm{~nm})$, UCPC 3025AS $(3 \mathrm{~nm})$ and CPC 3010AS $(10 \mathrm{~nm})$ ) by the University of Manchester (Whitehead et al., 2009).

\subsection{Model description}

A photochemical box model has been developed to investigate halogen chemistry at Roscoff using the Master Chemical Mechanism version 3.1 (MCM) (Jenkin et al., 1997; Saunders et al., 2003; Jenkin et al., 2003). The model contains reaction schemes for $\mathrm{C} 1-\mathrm{C} 4$ hydrocarbons which are subject to oxidation by $\mathrm{OH}, \mathrm{O}_{3}$ and $\mathrm{NO}_{3}$ (216 hydrocarbon species and approximately 580 reactions), and gas phase iodine and bromine chemistry (24 iodine and bromine species and approximately 100 iodine and bromine reactions). The differential equation solver FACSIMILE for Windows (MCPA software) was used to process the model. Photolysis rates of the halogen species were calculated from spectral radiometer measurements of the wavelength resolved actinic flux. 
The rate of heterogeneous loss due to uptake of gaseous species onto aerosol was calculated for each species, according to the aerosol volumetric surface area, reactive uptake coefficient and mean molecular speed using Eq. (3) (Ravishankara, 1997), and was treated as a permanent, irreversible loss. A constant aerosol volumetric surface area of $4 \times 10^{-6}$ $\mathrm{cm}^{2} \mathrm{~cm}^{-3}$ was used, representative of typical aerosol values measured during the campaign (Whitehead et al., 2009). Treating heterogeneous loss as a permanent loss for halogen species neglects aqueous processes which can result in the rerelease of gaseous halogen species (Pechtl et al., 2007; Vogt et al., 1999; McFiggans et al., 2000); the recycling of IO presented here may therefore represent a lower limit, but allows the magnitude of gas-phase recycling to be determined explicitly. A list of the halogen chemistry reaction scheme and heterogeneous loss parameters can be found in the Appendix Tables A1-A5.

$$
-\frac{d[X]}{d t}=k_{u}[X] \quad k_{u}=\frac{\omega A \gamma}{4} \quad \omega=\sqrt{\frac{8 R T}{\pi M}}
$$

where $k_{u}$ is the uptake rate coefficient, $A$ is the aerosol volumetric surface area, $\gamma$ is the reactive uptake coefficient, $\omega$ is the mean molecular speed of molecule $X, R$ is the molar gas constant, $T(\mathrm{~K})$ is the ambient temperature and $M$ is the molar mass.

\section{Results and discussion}

\subsection{Overview of LIF IO measurements}

The LIF instrument measured throughout the field campaign for a period of 20 days (7 September to 28 September 2008), see Fig. 3. Night-time measurements were made on four nights. IO was observed above the instrument limit of detection (0.4-4 pptv for a $150 \mathrm{~s}$ integration period, see Sect. 2.2) on 14 days (when no negative bias of the signal was observed, see Sect. 3.3), of which a clear diurnal profile was observed on 11 days; the maximum daytime IO detected was $30.0 \pm 7.1 \mathrm{pptv}$ ( $10 \mathrm{~s}$ integration period). IO concentrations were below the instrument's limit of detection or highly scattered around zero on the remaining days. There were three periods during the campaign when IO was not detected, which can be explained by a combination of lack of macroalgae exposure (neap tides) or meteorological conditions, as discussed below. Night-time IO was detected on two of the four nights of measurements, at mixing ratios of 1.1-2.0 pptv (60 min average).

The important influences on IO concentrations at the Roscoff site were found to be tidal height, solar irradiation, wind direction, wind speed and levels of $\mathrm{NO}_{\mathrm{x}}$. These will be discussed in the next section.

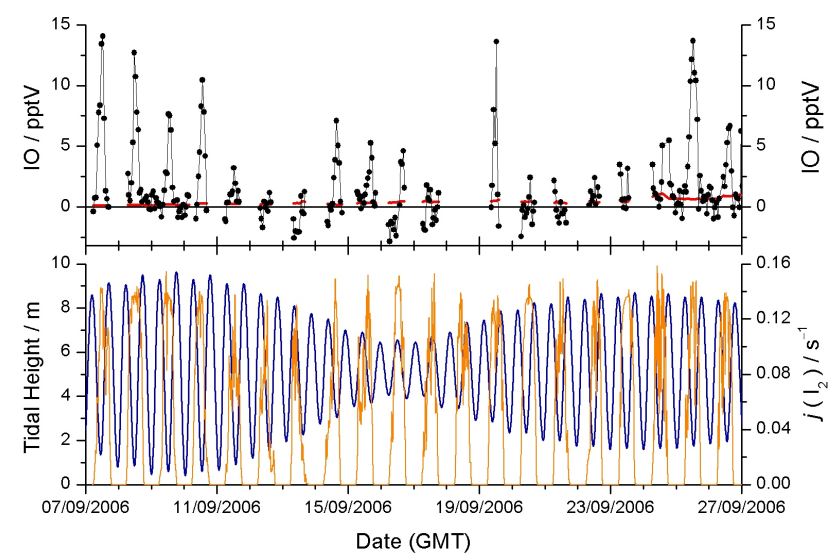

Fig. 3. Time series of IO measurements (23\% $1 \sigma$ uncertainty, 60 min average, black circles) for the duration of the campaign. Also shown is the IO detection limit (red line), tidal height (blue line) and $j\left(\mathrm{I}_{2}\right)$ (10 min average, orange line).

\subsection{Influences on daytime IO concentrations}

The concentration of IO at Roscoff was strongly dependent on tidal height and the intensity of solar irradiation, consistent with previous studies at similar locations and providing further evidence that the source of IO originates from emissions of iodine species from macroalgae beds that are exposed as the tide retreats (Peters et al., 2005; Saiz-Lopez et al., 2006b). The subsequent detection of IO was also dependent on meteorological conditions due to the LIF instrument being positioned at a distance from the iodine source (Fig. 1). Measurements of IO by LP-DOAS and multi-axis DOAS (MAX-DOAS) in the Gulf of Maine, where the island shores are populated with kelp, including the Laminaria species, did not show a tidal dependence (Stutz et al., 2007), emphasizing that not all coastal environments provide identical conditions.

IO concentrations (pptv) in the daytime displayed a clear anti-correlation with tidal height (TH, $\mathrm{m}$ ), as displayed in Fig. 4. The best fit expression to an exponential decay gave:

$[\mathrm{IO}]=10.05 \exp ^{(-\mathrm{TH} / 2.80)}-0.34, \quad R^{2}=0.90$

where $R^{2}$ is the statistical measure of how well the exponential decay approximates the data points. A second order polynomial and linear expressions also provide fits of similar confidence, however, $\left(R^{2}=0.89\right.$ and $R^{2}=0.90$, respectively) which illustrates that several mathematical dependencies may be used to describe the relationship. When comparing the second order polynomial dependence of daytime IO (pptv) on tidal height (m) to the same expression calculated by (Peters et al., 2005) at Lilia, a coastal site $\sim 40 \mathrm{~km}$ west of Roscoff, the expressions are similar, indicating that 


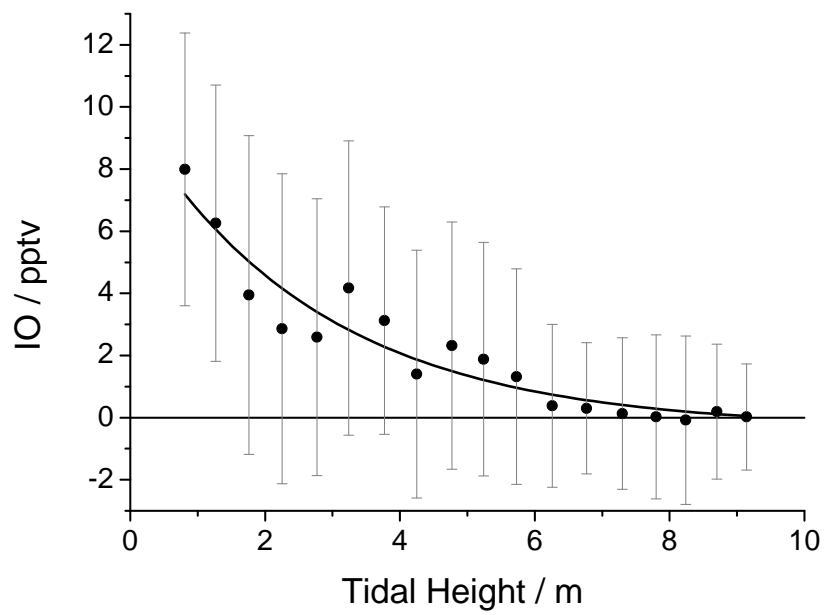

Fig. 4. The relationship between daytime IO and tidal height for the whole campaign (data binned according to $0.5 \mathrm{~m}$ width bins of tidal height), using $150 \mathrm{~s}$ averaged IO measurements. Error bars represent $\pm 1 \sigma$ standard deviation for all binned data. For each tidal height there is a range of $j\left(\mathrm{I}_{2}\right)$ depending on the time of day, and other parameters that influence $\mathrm{IO}$, such as $\mathrm{NO}_{\mathrm{x}}$ and meteorology. The solid line is an exponential decay fitted to the data, as given in the text by Eq. (4).

the exposure of macroalgae, and the subsequent release of $\mathrm{I}_{2}$, as the tide retreats may be similar at both locations:

Roscoff, $[\mathrm{IO}]=0.11 \times \mathrm{TH}^{2}-1.90 \times \mathrm{TH}+8.10$

Lilia, $[\mathrm{IO}]=0.13 \times \mathrm{TH}^{2}-1.95 \times \mathrm{TH}+7.28$

Solar irradiation is also essential for the production of IO because the production of IO results from the photolysis of iodine species; Fig. 5 shows the correlation that exists between IO concentrations and $j\left(\mathrm{I}_{2}\right)$. The photolysis of $\mathrm{I}_{2}$ to produce two I atoms has a relatively broader, flatter diurnal profile compared to the photolysis of $\mathrm{O}_{3}$ to produce $\mathrm{O}\left({ }^{1} \mathrm{D}\right)$ atoms, another important photochemical reaction resulting in the production of $\mathrm{OH}$, due to the broad absorption of $\mathrm{I}_{2}$ across the $\mathrm{UV}$ and visible spectrum, with a maximum absorption located between 500-600 nm (Saiz-Lopez et al., 2004). We can compare the IO diurnal profile from two days in the campaign during which IO originated from two different source regions (Fig. 6); the tidal minimum occurred at different times on each day. The 8 September was a clear day, providing a flat $j\left(\mathrm{I}_{2}\right)$ profile throughout the day, once it had risen from zero at dawn, the IO displays a large variation around the tidal minimum. The wind prevailed from macroalgae area A, close to the LIF inlet (Fig. 1) on this day. On 14 September solar irradiation was more variable and low tide fell late in the afternoon (wind prevailed from just north of macroalgae area C). On both of these days IO peaked at the tidal minimum. On 14 September, IO did not peak at solar noon/peak $j\left(\mathrm{I}_{2}\right)$. This scenario demonstrates that

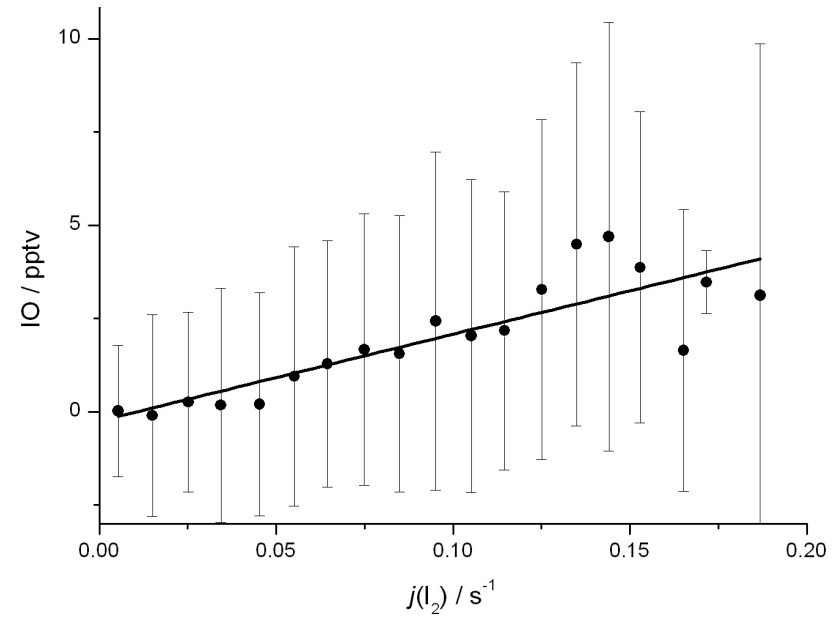

Fig. 5. Correlation plot displaying the relationship of IO with $j\left(\mathrm{I}_{2}\right)$ for daytime IO measurements (150 s average) throughout the whole measurement campaign. The data have been binned according to $0.01 \mathrm{~s}^{-1}$ sized bins. The error bars show the standard deviation of the $[\mathrm{IO}]$ in each $j\left(\mathrm{I}_{2}\right)$ bin.

macroalgae exposure is a prerequisite to daytime IO production, providing there is sufficient solar irradiation during the tidal minimum.

Wind speed and direction also influenced IO concentrations, see Fig. 7. We hypothesise that an air parcel must travel over an $\mathrm{I}_{2}$ emitting bed of macroalgae in order for IO to be detected by the LIF instrument. It also seems likely that the wind speed must be sufficiently high to transport IO to the LIF instrument before it is lost by chemical or physical removal (we return to this point in the subsequent sections).

Towards the end of the campaign, when IO levels returned to high values, the wind prevailed from the west to south west, where the macroalgae beds were located at a greater distance compared to northwest to easterly winds which prevailed earlier in the campaign (over $1000 \mathrm{~m}$ compared to $300 \mathrm{~m}$, see Fig. 1). This suggests that IO can be sustained as it is transported from more remote macroalgae beds.

The point source measurements of IO at the field site by the LIF instrument display an anti-correlation with point source $\mathrm{NO}_{\mathrm{x}}$ measurements (measured by the University of York chemiluminescent $\mathrm{NO}$ and $\mathrm{NO}_{2}$ instrument adjacent to the LIF instrument, see McFiggans et al., 2010 for details), as illustrated in Fig. 8. High concentrations of IO were not observed when $\mathrm{NO}_{\mathrm{x}}$ concentrations were high $\left(\mathrm{NO}_{2}\right.$ concentrations were generally between $1-5 \mathrm{ppbv}$ during the campaign), even at low tide, in contrast to IO measurements at Appledore Island, where $\mathrm{NO}_{2}$ was between 5-10 ppbv (Stutz et al., 2007). A time-series of highly time-resolved IO (10 s time resolution) and $\mathrm{NO}_{2}$ (Fig. 9) allows shorttimescale variations in the concentrations of these gases to be resolved. During mid-morning (10:30 GMT), when 

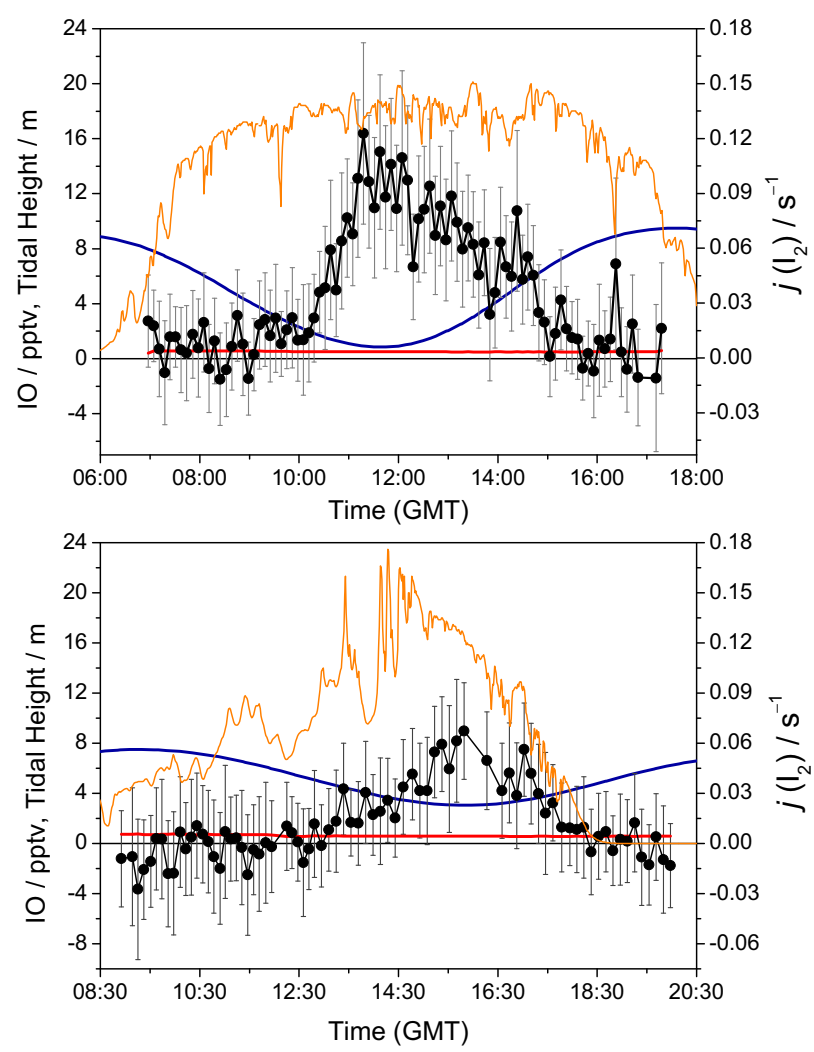

Fig. 6. Daytime IO profiles on 8 September (top) and 14 September (bottom). The black dots represent IO (150 s integration period, error bars represent the $23 \% 1 \sigma$ calibration error combined with the $1 \%$ error from the laser power normalisation and the $1 \sigma$ precision of the normalised signal), the red line represents the limit of detection ( $0.8 \mathrm{pptv}$ for $150 \mathrm{~s}$ integration period), the orange line represents $j\left(\mathrm{I}_{2}\right)$ and the blue line represents tidal height. A clear dependence of IO on tidal height is displayed as IO peaked at the tidal minimum. The bottom panel shows that IO peaked at the tidal minimum rather than peak $j\left(\mathrm{I}_{2}\right)$. The variability of IO in the morning and evening around zero is within one standard deviation of the background signal.

photolysis rates were increasing and tidal height was decreasing, there was a period of nearly 20 min when IO concentrations were suppressed, corresponding to a substantial $\mathrm{NO}_{2}$ spike of $2.1 \mathrm{ppbv}$. There is similar evidence for this at 09:50 GMT and later in the day but these periods also correspond to a drop in $j\left(\mathrm{I}_{2}\right)$. These two variables that influence IO cannot be differentiated in the latter examples. Throughout this day, the wind direction remained unchanged, although the airmass trajectory may have altered prior to sampling. In the presence of $\mathrm{NO}_{\mathrm{x}}$, I atoms and IO react to form the reservoir species $\mathrm{INO}_{2}, \mathrm{IONO}_{2}$ and INO (Reactions R10-R12). The reaction of NO with IO results in the release of reactive I atoms (Reaction 13).

$\mathrm{I}+\mathrm{NO}_{2}+\mathrm{M} \rightarrow \mathrm{INO}_{2}+\mathrm{M}$

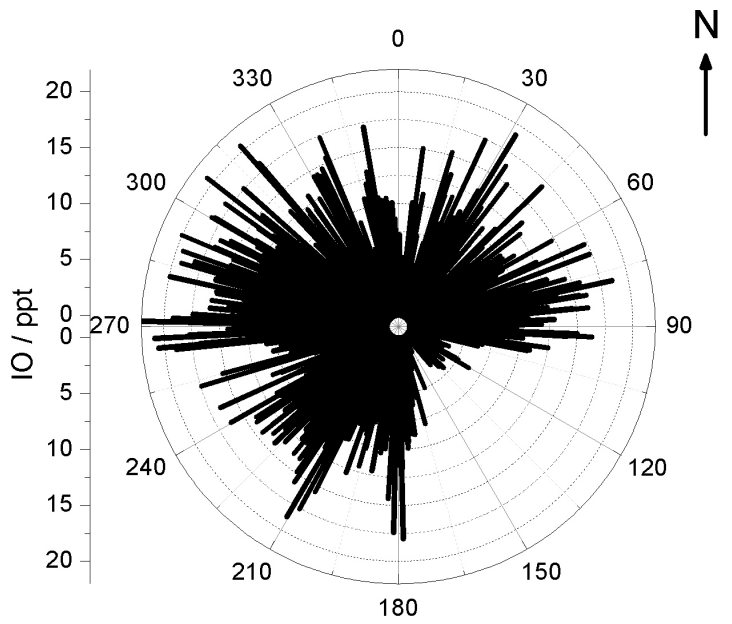

Fig. 7. A wind rose of IO concentrations to demonstrate the dependence of IO concentrations on wind direction (150 s averaged data for the entire campaign). A wind direction of 90 to 180 degrees corresponds to a prevailing wind from the town.

$\mathrm{IO}+\mathrm{NO}_{2}+\mathrm{M} \rightarrow \mathrm{IONO}_{2}+\mathrm{M}$

$\mathrm{I}+\mathrm{NO}+\mathrm{M} \rightarrow \mathrm{INO}+\mathrm{M}$

$\mathrm{IO}+\mathrm{NO} \rightarrow \mathrm{I}+\mathrm{NO}_{2}$

$\mathrm{OIO}+\mathrm{NO} \rightarrow \mathrm{IO}+\mathrm{NO}_{2}$

Model simulations were performed to explore the IO- $\mathrm{NO}_{\mathrm{x}}$ dependence. The MCM model was run using typical daytime conditions, with an injection of $100 \mathrm{pptv} \mathrm{I}_{2}$ at the start of the run. During the campaign, the LP-DOAS instrument measured up to $\sim 26 \mathrm{pptv}$ daytime $\mathrm{I}_{2}$ and the BBCRDS instrument measured up to $\sim 70 \mathrm{pptv}$. $\mathrm{I}_{2}$ levels were assumed to be higher than these measurements at the point of emission. $\mathrm{NO}_{\mathrm{x}}$ concentrations were varied from $0-10 \mathrm{ppbv}$ (ratio $\left.\mathrm{NO}_{2}: \mathrm{NO}=4: 1\right)$. All species were allowed to vary apart from $\mathrm{O}_{2}, \mathrm{~N}_{2}$ and $\mathrm{H}_{2} \mathrm{O}$ which were kept constant. The modelled [IO] after $50 \mathrm{~s} \mathrm{(solid} \mathrm{red)} \mathrm{and} 60 \mathrm{~s}$ (dashed red) time evolution are shown in Fig. 8 and present the best fit to the observed data. As is evident in the plot, the modelled IO also displays an anti-correlation with $\mathrm{NO}_{\mathrm{x}}$ (exponential decay fit, $[\mathrm{IO}]=1.00+11.8 \exp \left(-\left[\mathrm{NO}_{\mathrm{x}}\right] / 2.40\right), R^{2}=0.997$ at $t=50 \mathrm{~s}$ and $[\mathrm{IO}]=0.98+9.02 \exp \left(-\left[\mathrm{NO}_{\mathrm{x}}\right] / 2.49\right), R^{2}=0.996$ at $\left.t=60 \mathrm{~s}\right)$, although the modelled IO decays are shallower than the observed decay with respect to $\left[\mathrm{NO}_{\mathrm{X}}\right]$. The modelled anticorrelation exists because $\mathrm{NO}_{\mathrm{x}}$ acts to suppress IO primarily through the formation of $\mathrm{IONO}_{2}$ (Reaction R11). The impact of $\mathrm{NO}$ is lower than $\mathrm{NO}_{2} ; \mathrm{IONO}_{2}$ and $\mathrm{INO}_{2}$ were found to act as a greater IO reservoir compared to INO. NO (i) reacts with IO directly (resulting in the release of I atoms which can subsequently react with $\mathrm{O}_{3}$ to produce $\mathrm{IO}$, Reaction $\mathrm{R} 13$ ) and 


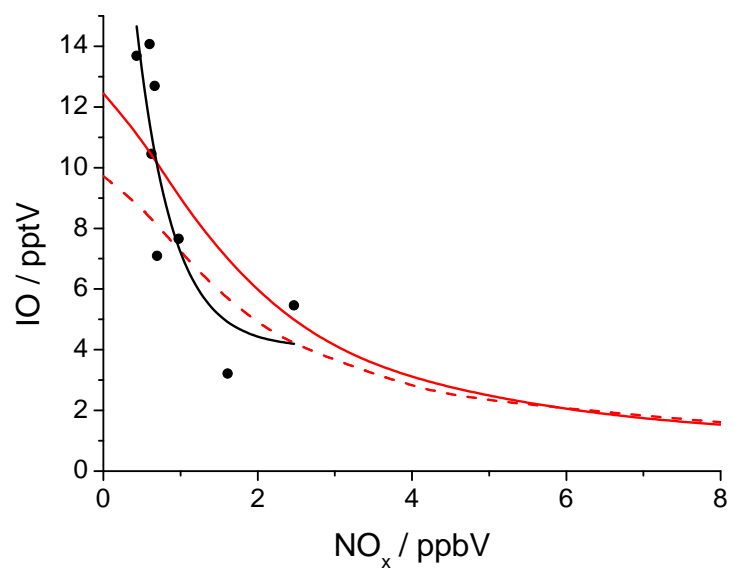

Fig. 8. The dependence of measured $\mathrm{IO}$ on $\mathrm{NO}_{\mathrm{x}}$ at peak [IO] (black circles). The graph shows how the measured peak [IO] (60 min average) varies with $\left[\mathrm{NO}_{\mathrm{x}}\right](60 \mathrm{~min}$ average, at the period of peak IO (30 min either side of peak IO)) for 8 days of the campaign when there was a clear IO diurnal (exponential decay fit, black line, $\left.[\mathrm{IO}]=4.06+26.6 \exp ^{\left(-\left[\mathrm{NO}_{\mathrm{x}}\right] / 0.50\right)}, R^{2}=0.77\right)$. Model results show a similar IO dependence on $\mathrm{NO}_{\mathrm{x}}$, [IO] at $50 \mathrm{~s}$ after $t=0 \mathrm{~s}$ (solid red line) and [IO] at $60 \mathrm{~s}$ after $t=0 \mathrm{~s}$ (dashed red line). Initialised with $100 \mathrm{pptv} \mathrm{I}_{2}$. Exponential decay fits: $[\mathrm{IO}]=1.00+11.8 \exp ^{\left(-\left[\mathrm{NO}_{\mathrm{x}}\right] / 2.40\right)}, R^{2}=0.997(t=50 \mathrm{~s}$, solid red line $),[\mathrm{IO}]=0.98+9.02 \exp ^{\left(-\left[\mathrm{NO}_{\mathrm{x}}\right] / 2.49\right)}, R^{2}=0.996(t=60 \mathrm{~s}$, dashed red line).

(ii) indirectly reduces IO by reaction with its I atom precursor (Reaction R12). NO is also involved in the release of IO via reaction with OIO (Reaction R14).

Kaltsoyannis and Plane (2008) recently proposed that at $\mathrm{IONO}_{2}: \mathrm{O}_{3}>0.01$, I atoms will preferentially react with $\mathrm{IONO}_{2}$ (Reaction R15) rather than $\mathrm{O}_{3}$ (Reaction R2) limiting the build up of this reservoir species and helping maintain IO concentrations in high $\mathrm{NO}_{\mathrm{x}}$ environments. Mahajan et al. (2009a) have found that the inclusion of this recycling mechanism was necessary to reproduce $\mathrm{I}_{2} / \mathrm{IO}$ ratios observed by LP-DOAS at Roscoff during the RHaMBLe campaign using a $1 \mathrm{D}$ model. Inclusion of this recycling mechanism in the $0 \mathrm{D}$ model used in this work reduces the anti-correlation observed between $\mathrm{IO}$ and $\mathrm{NO}_{\mathrm{x}}$. The modelled gradient becomes shallower still when the time between emission and sampling is increased further (the transit times from the major seaweed beds, highlighted in Fig. 1, to the LIF inlet ranged from less than $100 \mathrm{~s}$ to greater than $600 \mathrm{~s}$ )

$\mathrm{I}+\mathrm{IONO}_{2} \rightarrow \mathrm{I}_{2}+\mathrm{NO}_{3}$

Therefore, the anti-correlation of $\mathrm{IO}$ versus $\mathrm{NO}_{\mathrm{x}}$ observed may not be caused solely by chemical reactions between $\mathrm{IO}$ and $\mathrm{NO}_{\mathrm{x}}$. Rather, the relationship could be due also to the spatial heterogeneity of macroalgae and $\mathrm{NO}_{\mathrm{x}}$ sources (a point further discussed in McFiggans et al., 2010). Little or no IO was observed whenever the wind prevailed from

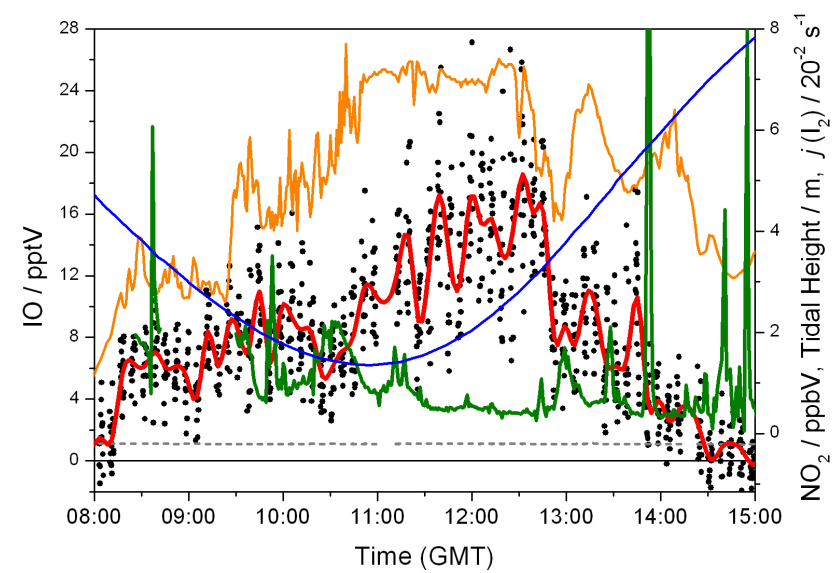

Fig. 9. The IO profile on 7 September. $\mathrm{An} \mathrm{NO}_{2}$ spike (green line) around 10:30 corresponds to a significant decrease in IO concentrations (black circles $=10 \mathrm{~s}$ integration period, red line $=150 \mathrm{~s}$ integration period). Also shown is the LIF detection limit (10 s integration period, dashed grey line), tidal height (blue line) and $j\left(\mathrm{I}_{2}\right)$ (orange line).

the town (Fig. 7) as no seaweed beds lay in this direction. Under such conditions $\mathrm{NO}_{\mathrm{x}}$ concentrations were elevated due to anthropogenic emissions, lending to an apparent anticorrelation. This IO- $\mathrm{NO}_{\mathrm{x}}$ relationship resolved by comparison of two point source techniques may not be discernible when comparing spatially averaged $\mathrm{IO}$ and $\mathrm{NO}_{2}$ measured by LP-DOAS instruments (e.g. Stutz et al., 2007) as spatial averaging will smooth out (to a certain extent) the heterogeneity of the $\mathrm{IO}$ and $\mathrm{NO}_{\mathrm{x}}$ sources.

\subsection{Measurements of IO at night}

The LIF instrument was run over 4 nights during the campaign. On two nights low mixing ratios (1-2 pptv) of IO were recorded around the tidal minimum (Fig. 10). On these nights the wind direction corresponded to a near $(300 \mathrm{~m})(8-$ 9 September) or far $(2800 \mathrm{~m})$ (25-26 September) source of $I_{2}$. An analysis of the Gaussian distribution of the deviation of the online and offline signal from the mean of the offline signal confirms that the signal is positive around the tidal minimum on $8-9$ and $25-26$ September. The results of this analysis on 8-9 September show that there is a positive signal between 00:00-02:00, compared to 23:00-00:00 and 02:00-03:00, when both online and offline signals correspond to zero (Fig. 11). The nighttime data are not significantly different from zero however. During the campaign the LP-DOAS instrument detected IO on three out of eight nights of measurements at up to $3.0 \pm 0.9 \mathrm{pptv}$. These measurements combined, although close to the LOD of the respective instruments, suggest a non-photolytic source of IO, as previously proposed by Chambers et al. (1992); Kaltsoyannis and Plane (2008), via Reaction (R3) followed by Reaction (R2). 

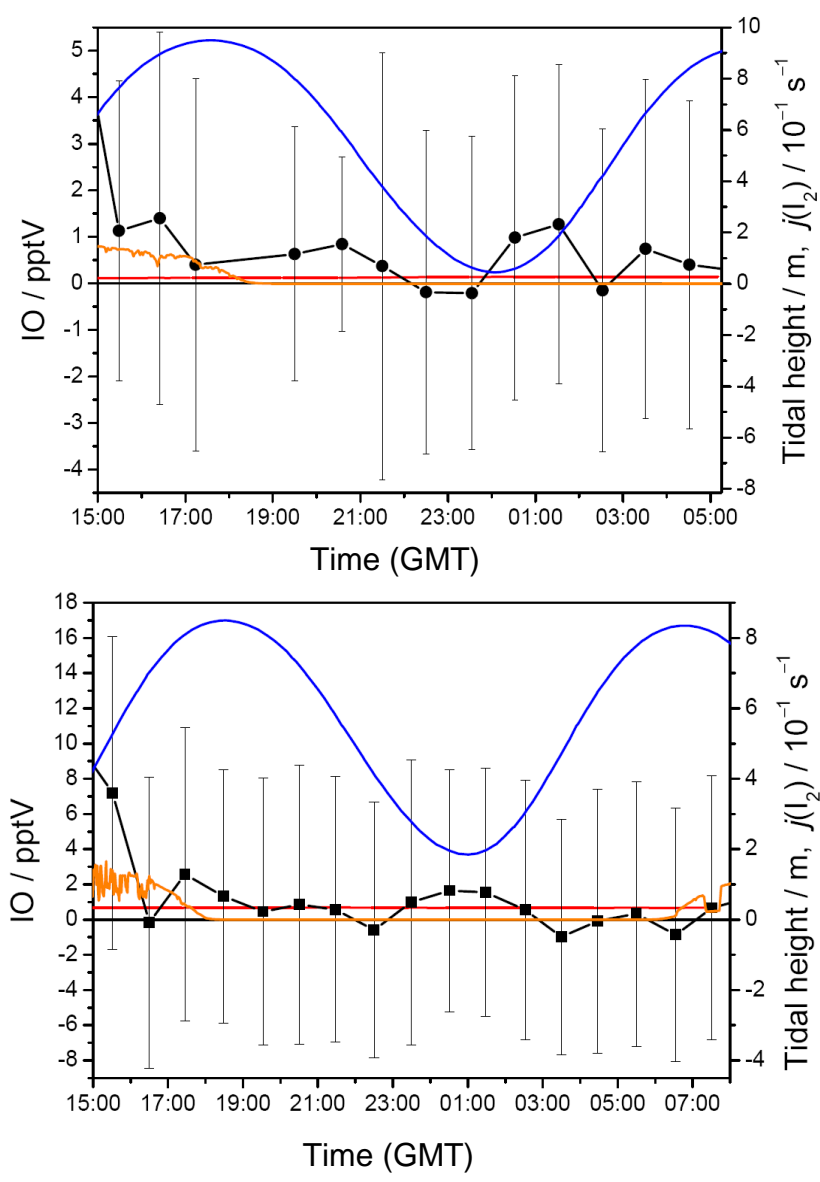

Fig. 10. Night-time measurement of IO on the nights of 8th (top) and 25th (bottom) September. The filled circles (top) and filled squares (bottom) represent IO (60 min average, black line represents 60 min running average, error bars represent the $23 \% 1 \sigma$ calibration error combined with the $1 \%$ error from the normalisation and the $1 \sigma$ precision of the normalised signal), the red line represents the $60 \mathrm{~min}$ limit of detection, the orange line represents $j\left(\mathrm{I}_{2}\right)$ and the blue line represents tidal height.

The proposed precursors of night-time IO $\left(\mathrm{I}_{2}\right.$ and $\left.\mathrm{NO}_{3}\right)$ were detected at the Roscoff site. Up to $52 \mathrm{pptv} \mathrm{I}_{2}$ was detected by LP-DOAS (Mahajan et al., 2009a) and 40-80 pptv $\left(\mathrm{NO}_{3}+\mathrm{N}_{2} \mathrm{O}_{5}\right)$ was detected by BBCEAS (Langridge et al., 2008).

A photochemical box model, constrained to these precursor concentrations (see Table 1), was used to examine the nighttime IO observations (model described in Sect. 2.3). Concentrations of the species listed in Table 1 and temperature $(288 \mathrm{~K})$ were constant throughout the model run, once initiated. The model was initiated at 23:00 and run to steady state IO conditions. Under these constraints, only very low IO mixing ratios $(\sim 0.4 \mathrm{pptv})$ were predicted by the model. To generate IO mixing ratios of $\sim 1-2$ pptv up to $320 \mathrm{pptv}$ of $\mathrm{I}_{2}$ was neccessary. This may suggest that the $\mathrm{I}_{2}$ concentration
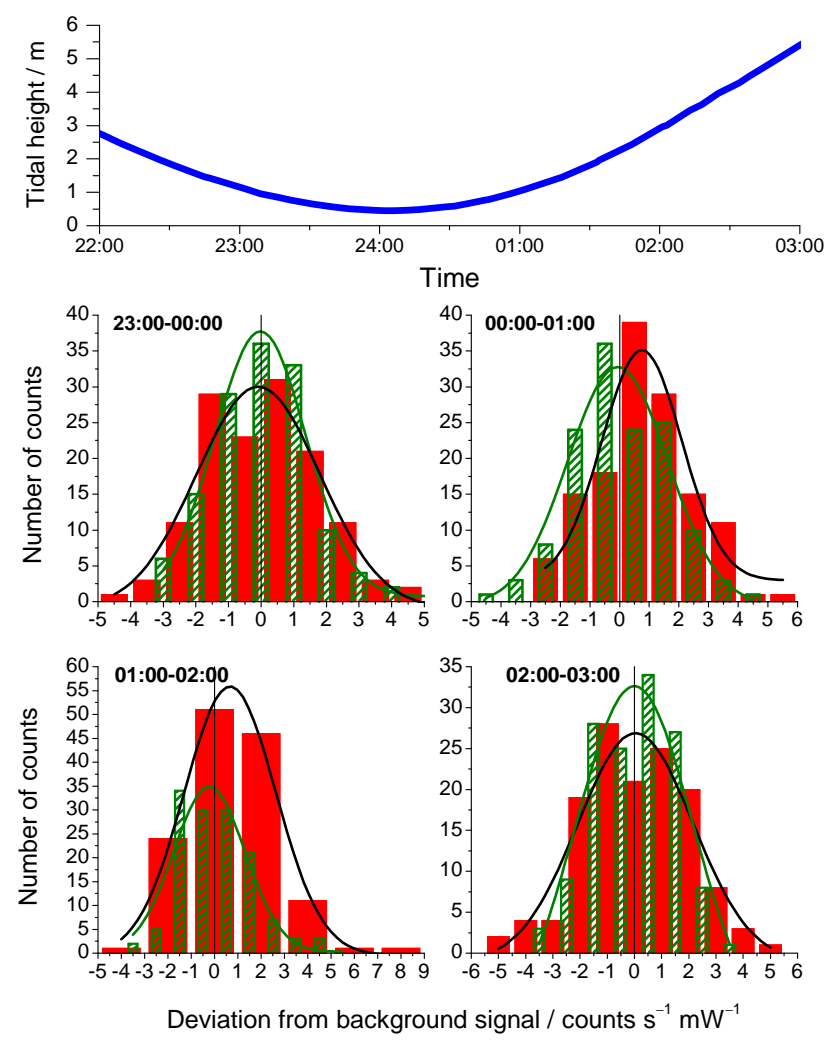

Fig. 11. Analysis of the Gaussian distribution of the LIF signal (middle and bottom panel) on the 8-9 September. The red columns represent the distribution of the online deviation from the background (corresponding Gaussian distribution fit is given by a black line) and the hatched green columns represent the distribution of the offline deviation from the mean of the background (corresponding Gaussian distribution fit is given by a green line). The signal is positive between 00:00-02:00, which is just after the tidal minimum (top panel, blue line). The offline Gaussian fit is centred close to zero in all cases.

at the macroalgae bed was higher than that measured by LPDOAS (and remained higher during transport to the LIF inlet); elevated point measurements of $\mathrm{I}_{2}$ detected by BBCRDS close to the LIF inlet (Leigh et al., 2009) support this hypothesis.

\subsection{Comparison of IO measurement techniques}

The RHaMBLe-Roscoff campaign was unique because it provided simultaneous, closely located measurements of IO by four different instruments. These were the LIF (University of Leeds, Whalley et al., 2007), LP-DOAS (University of Leeds, Plane and Saiz Lopez, 2006), Concurrent Multi Axis DOAS (CMAX-DOAS) (University of Leicester, Leigh et al., 2006) and Cavity Ringdown Spectroscopy (CRDS) (University of Bristol, Wada et al., 2007) instruments. Each instrument provided a different measurement 
Table 1. Summary of parameters used by the model to simulate night-time IO observations.

\begin{tabular}{lcc}
\hline Species & 8-9th & 25-25th \\
\hline $\mathrm{I}_{2} / \mathrm{pptv}$ & 50 & 50 \\
$\mathrm{CH}_{3} \mathrm{I} / \mathrm{pptv}$ & 0.5 & 0.5 \\
$\mathrm{CH}_{2} \mathrm{IBr} / \mathrm{pptv}$ & 0.02 & 0.02 \\
$\mathrm{DMS} / \mathrm{pptv}$ & 20 & 20 \\
$\mathrm{NO} / \mathrm{ppbv}$ & 0.033 & 0.117 \\
$\mathrm{NO}_{2} / \mathrm{ppbv}$ & 2.23 & 2.42 \\
$\mathrm{NO}_{3} / \mathrm{pptv}$ & 40 & 40 \\
$\mathrm{O}_{3} / \mathrm{ppbv}$ & 31.6 & 19.2 \\
\hline
\end{tabular}

footprint. DOAS instruments provide spatially averaged measurements and have been deployed to measure IO at a variety of sites. The most recent review of IO measurements can be found in (von Glasow and Crutzen, 2007). The addition of novel LIF and CRDS instruments provide pointsource measurements, enabling a greater interpretation of iodine chemistry at this site, for example the extent of the spatial heterogenity (or hot-spots) of the iodine sources. The LIF instrument also provided a high temporal resolution (10 second integration period during this field campaign), which reveals the high temporal variability of IO (see Fig. 9) possibly caused by fast fluctuations in the concentrations of other trace gases, for example $\mathrm{I}_{2}$ or $\mathrm{NO}_{\mathrm{x}}$, changes in meteorological conditions (wind speed, wind direction, solar irradiation) or changes in the exposure of macroalgae beds as the tide retreats.

The LP-DOAS instrument provided measurements over an average of a $6.7 \mathrm{~km}$ light path at a height of 7 to $12 \mathrm{~m}$ above the mean sea level (Fig. 1). IO was retrieved in a $425-445 \mathrm{~nm}$ spectral window, which also includes $\mathrm{NO}_{2}$ and $\mathrm{H}_{2} \mathrm{O}$. The CMAX-DOAS provided slant column measurements (telescopes pointing $2^{\circ}$ and $5^{\circ}$ north, $5^{\circ}$ east and $5^{\circ}$ west (viewing angles above the horizon)) using a retrieval window between 434 and $459 \mathrm{~nm}$, to include the absorption bands of IO at 436,445 and $456 \mathrm{~nm}$, further details can be found in McFiggans et al. (2010). The LIF, CRDS and CMAX-DOAS instruments were all located within $\sim 7 \mathrm{~m}$ of each other (Fig. 2). The LP-DOAS instrument was located $\sim 25 \mathrm{~m}$ from the other instruments. A comparison of the four instruments is given in Table 2.

During the RHaMBLe-Roscoff field campaign the LIF IO and LP-DOAS instruments were measuring IO simultaneously on seven days. When both instruments were measuring simultaneously, there was never an instance of IO detection by the LIF instrument and not the LP-DOAS instrument. Meteorological and $\mathrm{NO}_{\mathrm{x}}$ conditions on 8 and 9 September were similar but IO concentrations measured by the two instruments were very different. The 17 September is an example of positive detection of IO by the LP-DOAS instrument in the absence of detection by the LIF IO instrument. CMAX-
Table 2. Summary of the performance of the IO measurement techniques. Instrument detection limits are an average daytime value for 8 September. Detection limits are quoted as mixing ratios except the CMAX-DOAS measurements, which is a slant column.

\begin{tabular}{ccc}
\hline Instrument & Detection Limit & Integration Period \\
\hline LIF & $0.4 \mathrm{pptv}$ & $150 \mathrm{~s}$ \\
& $1.1 \mathrm{pptv}$ & $10 \mathrm{~s}$ \\
LP-DOAS & $0.6 \mathrm{pptv}$ & $60 \mathrm{~s}$ \\
CRDS & $12 \mathrm{pptv}$ & $30 \mathrm{~s}$ \\
CMAX-DOAS & $1.64 \times 10^{13}$ molecule cm & $15 \mathrm{~min}$ \\
\hline
\end{tabular}

DOAS measurements are also used to give information about the spatial IO distribution, but the CRDS measurements are not considered due to the small number of coincident observations made.

\subsubsection{8 and 9 September 2006}

During the 8 to 9 September meteorological conditions were similar. Winds were easterly (corresponding to macroalgae area A, Fig. 1) and wind speeds were relatively high. Photolysis rates were similar on both days. The tidal range was at a maximum (spring tide) with low tide around midday. Five day back trajectory analysis shows that the air mass was North Sea in origin, approaching from the east and descending over France. On the 9 September the air mass approached the site from a slightly more south east direction, with slightly lower wind speeds (4-5 $\mathrm{ms}^{-1}$ compared to 5.5$6.5 \mathrm{~ms}^{-1}$, measured at the LIF container). Concentrations of $\mathrm{NO}$ were 0.18 and $0.22 \mathrm{ppbv}$. An increase of $\sim 50 \%$ from 0.54 to 0.82 ppbv was observed in $\mathrm{NO}_{2}$ from 8 th to 9 th (average concentrations for a period of one hour around peak IO). The LP-DOAS $\mathrm{NO}_{2}$ measurement was twice that on the 9 September compared to the 8 September $(0.7$ to $1.5 \mathrm{ppbv}$, 10:00-14:00).

The IO diurnal profiles are displayed together in Fig. 12. The LP-DOAS measurements display a lower degree of variability compared to the LIF measurements, resulting from the $3.35 \mathrm{~km}$ path length that the LP-DOAS measurements are averaged over, resulting in measured IO being smoothed out spatially. The measurements show that on 8 September the LIF IO instrument measured approximately twice that of the LP-DOAS instrument. However, on 9 September both instruments measured approximately the same peak concentrations. On both days, the ratio of LIF IO:LP-DOAS IO increases after low tide, indicating that the LIF instrument observes higher concentrations of IO for a longer time period, later in the day.

This relationship can be explained by examining the local wind direction and the air mass transport time from source region to the LIF instrument or LP-DOAS light path. On the 9 September the air mass was approaching from a slightly more south easterly direction than on the 8 th. From this 


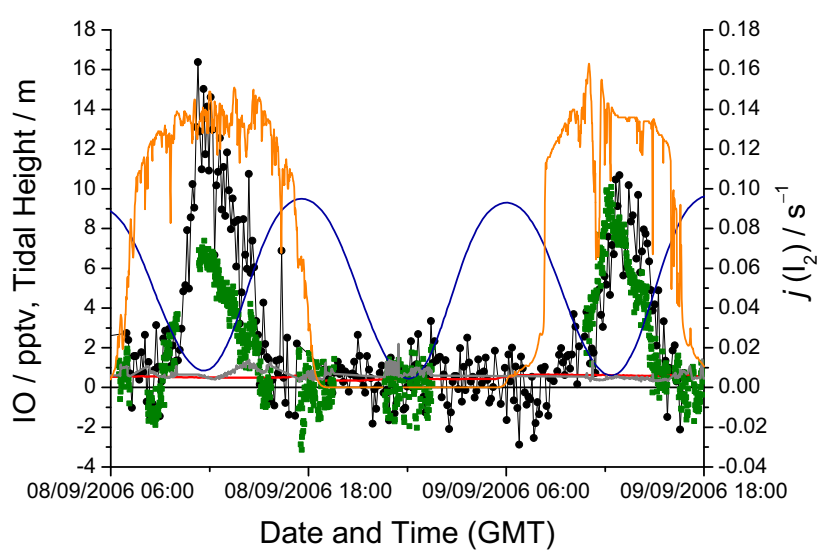

Fig. 12. Time series of $150 \mathrm{~s}$ integration period LIF IO measurements (black circles) and 1 min LP-DOAS IO measurements (green squares) from 8 to 9 September. Also shown is the LIF detection limit (red line), LP-DOAS detection limit (grey line), tidal height (blue line) and $j\left(\mathrm{I}_{2}\right)$ (orange line).

direction, air flowed along the LP-DOAS light path axis rather than slightly off-axis (as was the case on the 8th). Under the conditions experienced on the 9th we would expect the LP-DOAS instrument to detect higher concentration of IO than on the 8th as a greater proportion of the light path was filled by air that had passed over $\mathrm{I}_{2}$ source regions. In contrast to this, owing to the lower wind speeds experienced on the 9th, we would expect the LIF instrument to detect lower IO concentrations on this day compared with the 8th as the time taken for an air mass to travel from the macroalgae beds to LIF inlet increases, allowing chemical reactions to decrease IO concentrations further.

Further insight into the LIF:LP-DOAS relationship can be gained by studying CMAX-DOAS measurements of IO. The CMAX-DOAS and LIF instruments observed the same daily variation in IO concentrations (Fig. 13), both instruments detecting higher levels of IO on 8 September. Like LIF measurements, CMAX-DOAS IO persists longer after peak IO compared to LP-DOAS measurements. On both days, the $5^{\circ}$ northerly CMAX-DOAS telescope observed higher concentrations of IO compared to the westerly telescope. On the 9 th, the ratio of the north to west was greater than on the 8th indicative of a slightly more southerly source to which the LP-DOAS instrument is more responsve to.

\subsubsection{September 2006}

The 17 September provides an example of the positive detection of IO by LP-DOAS with corresponding LIF measurements of IO close to the instrument's detection limit (Fig. 14). No other IO instrumentation was operating on this day. The LP-DOAS instrument detected $6.8 \pm 2.4$ pptv of IO, around low tide. The LIF instrument detected very low con-

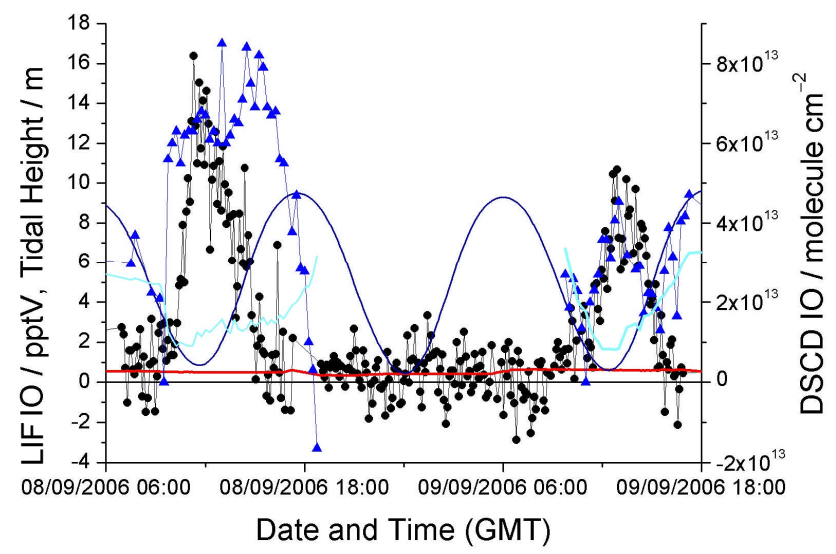

Fig. 13. Time series of $150 \mathrm{~s}$ integration period LIF IO mixing ratio measurements (pptv, black circles) and 15 min CMAXDOAS Differential Slant Column Density (DSCD) IO measurements (molecule $\mathrm{cm}^{-2}$, blue triangles, $5^{\circ}$ north-facing telescope) from 8 to 9 September. Also shown is the LIF detection limit (red line), CMAX-DOAS detection limit (light blue line) and tidal height (blue line).

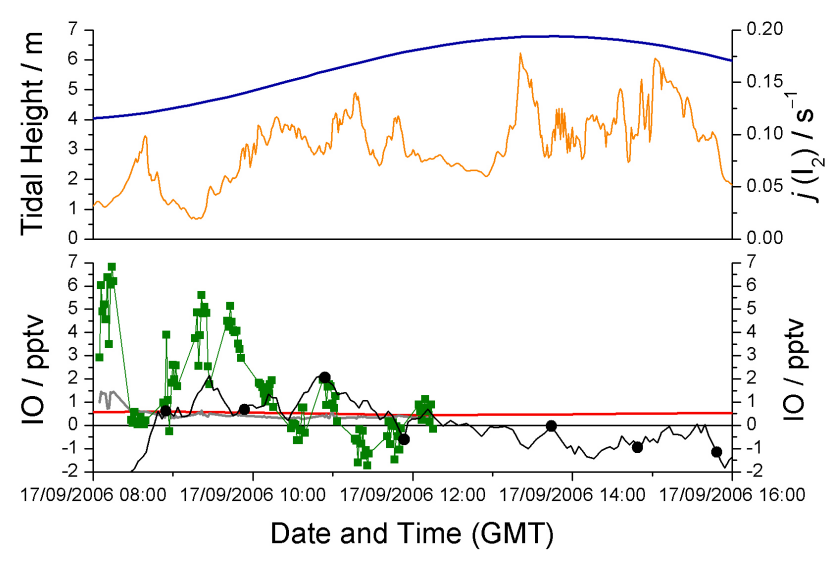

Fig. 14. Top: Tidal height (blue line) and $j\left(\mathrm{I}_{2}\right)$ (orange line). Bottom: Time series of $1000 \mathrm{~s}$ integration period LIF IO measurements (black circles) and 1 min LP-DOAS IO measurements (green squares) on 17 September. Also shown is the LIF detection limit (red line) and LP-DOAS detection limit (grey line).

centrations close to the detection limit (0.5-0.6 pptv, 1000 $\mathrm{s}$ integration period) with a possible positive peak just after low tide on 17 September (upper limit $2.1 \mathrm{pptv}$ ). The LIF instrument did not detect IO because of the low tidal range, and low tide fell in the morning when solar irradiation was low. Additionally, a combination of medium strength winds $\left(2.5-3.5 \mathrm{~ms}^{-1}\right)$ prevailing from macroalgae beds which were far from the LIF instrument (over $1 \mathrm{~km}$, Fig. 1, area C) result in the requirement for a long time period to sustain IO levels (over $\sim 330 \mathrm{~s}$ from macroalgae bed to LIF cell). Owing to 


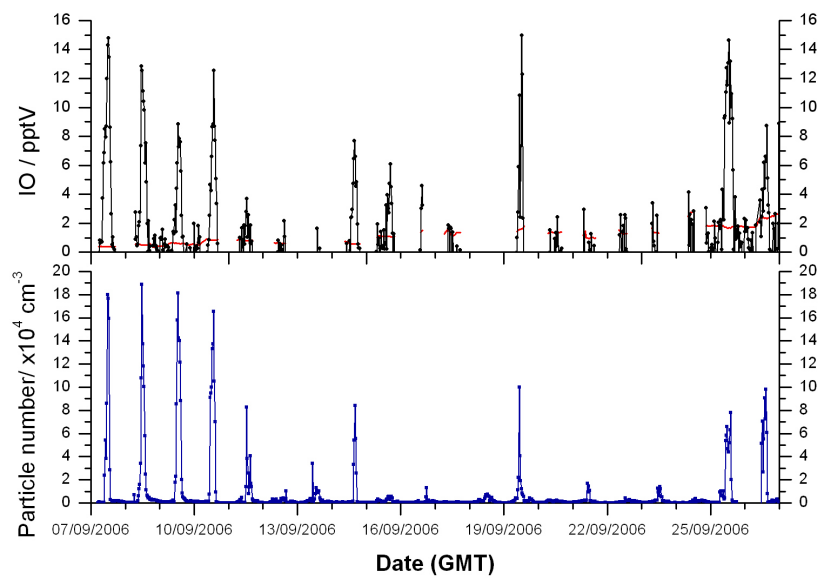

Fig. 15. Time series of IO and particle measurements at Roscoff throughout the campaign. The top panel shows $30 \mathrm{~min}$ averaged IO concentrations (black line) with the corresponding 30 min detection limit (red line). No IO measurements were made on 18 September. The bottom panel shows $30 \mathrm{~min}$ averaged particle number counts for $2.5 \mathrm{~nm}<d<10 \mathrm{~nm}$ (blue line).

the positioning of the LP-DOAS light-path, macroalgae bed C, (Fig. 1) was much closer to the LP-DOAS sampling axis than the LIF sampling point and was able to detect significant IO concentrations originating from this region.

The measurement of differing IO mixing ratios by LIF compared to spatially averaged techniques (LP-DOAS) provides strong evidence that IO is not uniformly distributed at Roscoff, an environment where the major source of iodine species are macroalgae.

\subsection{Particle formation and iodine oxides}

IO is an essential precursor to the iodine-mediated proposed reaction mechanism for the production of ultra-fine particles, therefore coordinated in situ measurement of both may enable a better understanding of their relationship. The results from this campaign provide 18 days when co-located $\mathrm{IO}$ and particle counter instruments were operating (located $\sim 15 \mathrm{~m}$ apart, see Fig. 2). Measurements of particle number above diameter $2.5 \mathrm{~nm}(3.0 \mathrm{~nm}$ from 11 September) and $10 \mathrm{~nm}$ were made; the difference between the two measurements provided a number count in the $2.5 \mathrm{~nm}$ (or $3.0 \mathrm{~nm}$ )$10 \mathrm{~nm}$ diameter range. The campaign time series is shown in Fig. 15. The results show that ultrafine particle events $(2.5 \mathrm{~nm}<$ diameter $(d)<10 \mathrm{~nm})$ correlate with elevated concentrations of IO. There is one anomalous day (15 September), when IO concentrations are elevated yet there is an absence of particles. Figure 16 shows a correlation plot of peak particle number $(2.5 \mathrm{~nm}<d<10 \mathrm{~nm})$ versus peak IO for the 18 days of coincident measurements. This plot provides direct evidence that the nucleation source of particle bursts at Roscoff and other similar marine environments is

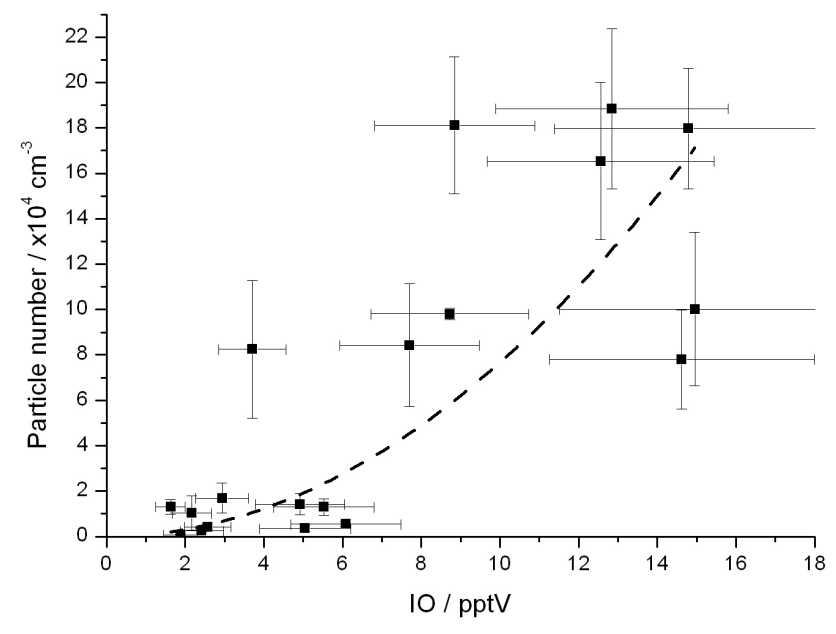

Fig. 16. Correlation plot of peak particle counts (30 min average, $2.5 \mathrm{~nm}<d<10 \mathrm{~nm}$ ) against peak IO mixing ratio (30 min average), with $1 \sigma$ error, from 7 to 17 September. The dotted line shows a power fit (Particle number $\times 10^{4} \mathrm{~cm}^{-3}=0.08 \times[\mathrm{IO}]^{2}$ ).

proportional to IO. From the proposed reaction mechanism for particle formation from IO precursors (Sect. 1) we would expect a quadratic dependence (or higher) to exist between these two species; a power expression of the type $y=a x^{2}$ is fitted to the data for reference - see Fig. 16 for details. The data points in Fig. 16 originate from a variety of macroalgae source regions (both close to and further from the measurement point), assuming that IO and particles are from the same $\mathrm{I}_{2}$ source regions, the correlation between particle number and IO concentration provides evidence that the I atom/IO couplet is quite persistent despite the short IO photolysis lifetime; this coupling efficiently buffers the IO concentration and preserves the particle vs IO correlation. As shown in Fig. 17, the IO concentration displayed a broader profile compared to particle number, IO tended to increase between 75 to 160 min before particle number increased and fell up to $75 \mathrm{~min}$ after particle number had fallen. There was, however, some variability in the temporal profile of each species, for example, when the wind direction corresponded to an iodine source close to the measurement site (Fig. 1, area A) the rise in IO was rapid and particle number increased from background levels earlier; observed on the 8 September (Fig. 17). On the days when the iodine source was further from the field site (areas B and C), and the rise in IO concentration was slower, the rise in particle number begins later (relative to the rise in IO), such as observed on the 7 September. Particle formation is at least second order in OIO, and, therefore, at least 4th order in IO. As a consequence of this, at the lower IO concentrations the particle production potential will be extremely small, as IO concentrations increase, the particle production potential becomes measurable, lending to the much broader IO profile observed relative to the particle 


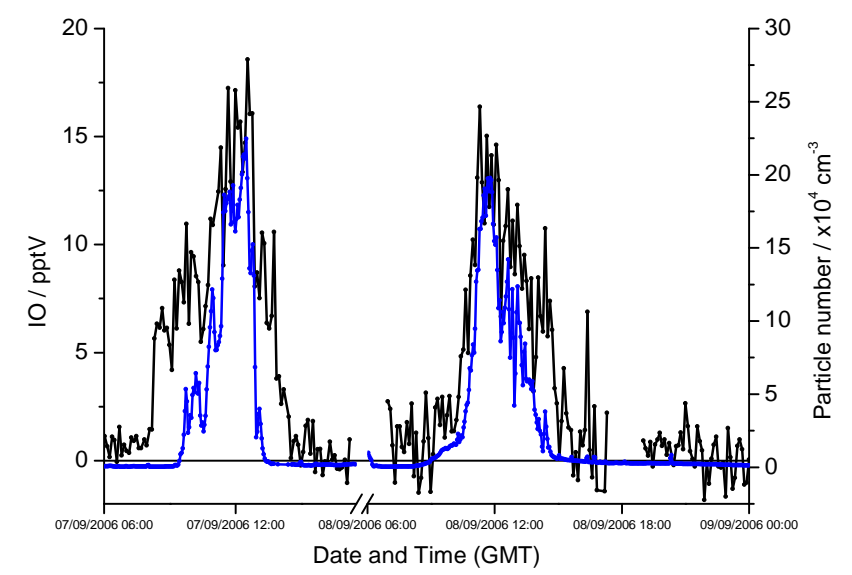

Fig. 17. [IO] (black) and particle number $(2.5 \mathrm{~nm}<d<10 \mathrm{~nm}$, blue $)$ on 7 and 8 September. IO displays a broader profile than particle number on the 7 th. This is not observed to the same extent on the 8 th, see text for further details.

number profile. These results provide direct evidence that IO is involved in the mechanism of new particle formation at coastal sites and supports the link between photochemi$\mathrm{cal} \mathrm{O}_{3}$ destruction and particle formation at marine locations, discussed further in Whitehead et al. (2009).

\section{Modelling study: impact of iodine chemistry on daytime $\mathrm{HO}_{\mathrm{x}}$ levels}

The dominant daytime oxidant, $\mathrm{OH}$, is closely coupled to $\mathrm{HO}_{2}$ through reactions with trace gases. In polluted environments $\mathrm{HO}_{2}$ is converted to $\mathrm{OH}$ via reaction with $\mathrm{NO}$ (Reaction R16). In low $\mathrm{NO}$ environments, the conversion of $\mathrm{HO}_{2}$ to $\mathrm{OH}$ proceeds via reaction with $\mathrm{O}_{3}$ (Reaction $\left.\mathrm{R} 17\right)$. The presence of halogen monoxides ( $\mathrm{XO}$, where $\mathrm{X}=\mathrm{I}$ or $\mathrm{Br}$ or $\mathrm{Cl}$ ) provides an alternative two step route for $\mathrm{HO}_{2}$ to $\mathrm{OH}$ conversion (Reactions R18 and R19). Previous modelling studies (Davis et al., 1996; Stutz et al., 1999; Bloss et al., 2005, 2007; Read et al., 2008; Whalley et al., 2010) have found that the presence of iodine species leads to an enhancement of $\mathrm{OH}$ due to the conversion of $\mathrm{HO}_{2}$ to $\mathrm{OH}$ via reaction with $\mathrm{IO}$. In contrast, Keene et al. (2009) found that $\mathrm{OH}$ concentrations decreased in the presence of $\mathrm{ClO}$ due to an increase in oxidation of $\mathrm{NO}_{\mathrm{x}}$ and corresponding reduction in Reaction (R16). Here we consider the impact of $\mathrm{IO}$ only on $\mathrm{HO}_{\mathrm{x}}$ levels.

$$
\begin{aligned}
& \mathrm{HO}_{2}+\mathrm{NO} \rightarrow \mathrm{OH}+\mathrm{NO}_{2} \\
& \mathrm{HO}_{2}+\mathrm{O}_{3} \rightarrow \mathrm{OH}+2 \mathrm{O}_{2} \\
& \mathrm{HO}_{2}+\mathrm{XO} \rightarrow \mathrm{HOX}+\mathrm{O}_{2} \\
& \mathrm{HOX}+\mathrm{h} v \rightarrow \mathrm{OH}+\mathrm{X}
\end{aligned}
$$

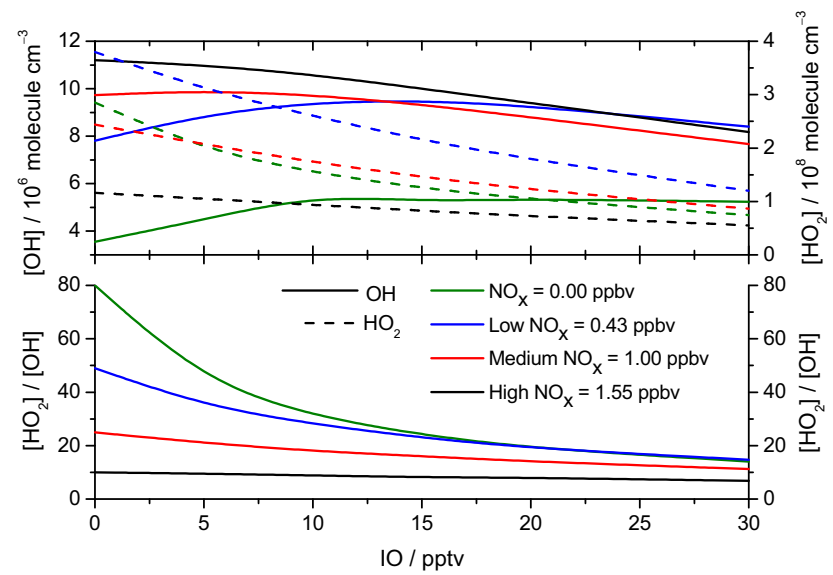

Fig. 18. The effect of $\mathrm{IO}$ on $\mathrm{OH}$ and $\mathrm{HO}_{2}$ concentrations and the $\mathrm{HO}_{2} / \mathrm{OH}$ ratio at noon at different fixed $\mathrm{NO}_{\mathrm{x}}$ concentrations (low $\mathrm{NO}_{\mathrm{x}}$ scenario, $\mathrm{NO}_{\mathrm{x}}=0.43$ ppbv, medium $\mathrm{NO}_{\mathrm{x}}$ scenario, $\mathrm{NO}_{\mathrm{x}}=1$ ppbv, high $\mathrm{NO}_{\mathrm{x}}$ scenario, $\mathrm{NO}_{\mathrm{x}}=1.55 \mathrm{ppbv}$ ). The plot shows how $\mathrm{HO}_{\mathrm{x}}$ concentrations vary with increasing IO. The solid line represents $[\mathrm{OH}]$ and the dashed line represents $\left[\mathrm{HO}_{2}\right]$. The bottom plot represents the $\mathrm{HO}_{2} / \mathrm{OH}$ ratio.

A photochemical box model (see Sect. 2.3 and Appendix Tables A1-A5 for full mechanism) has been used to investigate the effect of iodine chemistry on $\mathrm{HO}_{\mathrm{x}}$ concentrations under different $\mathrm{NO}_{\mathrm{x}}$ conditions, relevant to the RHaMBLeRoscoff campaign when reasonably high levels of $\mathrm{NO}_{\mathrm{x}}(1-$ 5 ppbv) were experienced due to the close proximity of the measurement site to the town. Model calculations for four different $\mathrm{NO}_{\mathrm{x}}$ scenarios were run (zero, low, medium and high $\mathrm{NO}_{\mathrm{x}}$ concentrations), representative of conditions experienced during the campaign. The model was initiated at midnight and run to noon time steady state $\mathrm{HO}_{\mathrm{x}}$ conditions. Concentrations of $\mathrm{NO}, \mathrm{NO}_{2}, \mathrm{CO}, \mathrm{CH}_{4}$, non-methane hydrocarbons (C2-C4), $\mathrm{O}_{3}, \mathrm{CH}_{3} \mathrm{I}, \mathrm{CH}_{2} \mathrm{IBr}$ and $\mathrm{IO}$ and uptake coefficients onto aerosol (Table A5) were kept constant. This allowed the effect of iodine chemistry on $\mathrm{HO}_{\mathrm{x}}$ to be evaluated under different IO loadings.

A baseline zero $\mathrm{NO}_{\mathrm{x}}$ scenario was run as a comparison case. As expected, increasing IO results in an increase of $\mathrm{OH}$ at the expense of $\mathrm{HO}_{2}$, via Reactions (R18) and (R19), decreasing the $\left[\mathrm{HO}_{2}\right] /[\mathrm{OH}]$ ratio (Fig. 18). As $\mathrm{NO}_{\mathrm{x}}$ concentrations increase, the influence of iodine chemistry on $\mathrm{HO}_{\mathrm{x}}$ decreases. The presence of IO in a low $\mathrm{NO}_{\mathrm{x}}$ scenario $\left(\mathrm{NO}=0.075 \mathrm{ppbv}, \mathrm{NO}_{2}=0.357 \mathrm{ppbv}\right.$ ) results in the enhancement of $\mathrm{OH}$ up to a critical point of $\mathrm{IO}=15 \mathrm{pptv}$. Above these IO levels, $\mathrm{OH}$ levels decrease. The critical IO concentration decreases as $\mathrm{NO}_{\mathrm{x}}$ increases until a point when the presence of $\mathrm{IO}$ always results in a decrease of $\mathrm{OH}$.

A rate of production analysis shows that in a low $\mathrm{NO}_{\mathrm{x}}$ environment the conversion of $\mathrm{HO}_{2}$ to $\mathrm{OH}$ via IO (Reactions R18 and R19) is always greater than via NO 


\section{Appendix A}

Table A1. Halogen chemistry reaction scheme - unimolecular reactions.

\begin{tabular}{lll}
\hline Unimolecular reactions & \\
\hline Reaction & Rate coefficient $/ \mathrm{s}^{-1}$ & Reference \\
\hline $\mathrm{INO}_{2} \rightarrow \mathrm{I}+\mathrm{NO}_{2}$ & $(2.4 / 0.005) 2.07 \times 10^{15} \mathrm{exp}(-11859 / T)$ & Saiz-Lopez et al. (2008) \\
$\mathrm{IONO}_{2} \rightarrow \mathrm{IO}+\mathrm{NO}_{2}$ & $2.1 \times 10^{15} \exp (-13670 / T)$ & Sander et al. (2006) \\
$\mathrm{I}_{2} \mathrm{O}_{2} \rightarrow \mathrm{I}+\mathrm{OIO}$ & 10 & Kaltsoyannis and Plane (2008) \\
$\mathrm{I}_{2} \mathrm{O}_{2} \rightarrow 2 \mathrm{IO}$ & 0.045 & Kaltsoyannis and Plane (2008) \\
$\mathrm{I}_{2} \mathrm{O}_{4} \rightarrow 2 \mathrm{OIO}$ & 0.038 & Kaltsoyannis and Plane (2008) \\
$\mathrm{BrNO}_{3} \rightarrow \mathrm{BrO}+\mathrm{NO}_{2}$ & $2.8 \times 10^{13} \exp (-12360 / T)$ & Orlando and Tyndall (1996) \\
\hline
\end{tabular}

(Reaction R16) and the Reactions (R13) and (R11) are slow. Under high $\mathrm{NO}_{\mathrm{x}}$ conditions, the conversion of $\mathrm{HO}_{2}$ to $\mathrm{OH}$ via NO dominates. The presence of IO suppresses Reaction (R16) by reaction of IO with $\mathrm{NO}$ and $\mathrm{NO}_{2}$ (Reactions R13 and R11).

The high concentrations of IO measured at Roscoff (up to 30 pptv) under variable $\mathrm{NO}_{\mathrm{x}}$ concentrations will impact local air quality by impacting the local $\mathrm{OH}$ and $\mathrm{HO}_{2}$ levels. As $\mathrm{NO}_{\mathrm{x}}$ concentrations increase $\mathrm{OH}$ to $\mathrm{HO}_{2}$ conversion becomes less significant, until the presence of IO results in a decrease of $\mathrm{OH}$. The presence of halogens can actually decrease the oxidative capacity of the atmosphere at the higher $\mathrm{NO}_{\mathrm{x}}$ concentrations experienced.

\section{Conclusions}

The results presented from the RHaMBLe-Roscoff campaign represent the first measurement of ambient IO by LIF. From 20 days of measurements, IO was observed above the instrument limit of detection on 14 days, of which a clear diurnal profile was observed on 11 days. IO concentrations were below the instrument's limit of detection or highly scattered around zero on the remaining days. The maximum IO measured was $30.0 \mathrm{pptv}$ over a $10 \mathrm{~s}$ integration period (limit of detection=1.4 pptv for $10 \mathrm{~s}$ ). A strong dependence of IO concentrations on tidal height was found. Additionally, the main influences on IO concentrations were the intensity of solar irradiation, wind direction and wind speed. This cements confidence in the hypothesis that the source of IO is emission of halogen species from macroalgae when the latter are exposed during low tide. During the day, solar irradiation is necessary to provide a photolytic source of I atoms. The night-time measurements of IO during this study provide further evidence of a non-photolytic source of IO via reaction of $\mathrm{I}_{2}$ with $\mathrm{NO}_{3}$ (Chambers et al., 1992).

A comparison of point source and spatially averaged IO measurements show that point source LIF measurements can be at least twice that of spatially averaged LP-DOAS measurements. This provides strong evidence that IO is not uni- formly distributed in an environment where the major source of iodine species are macroalgae. IO concentrations detected by the LIF instrument represent a more applicable constraint in modelling studies when the supporting measurements are also point sources. The practice of scaling up IO measured using LP-DOAS to account for hot-spots of IO along the light path is verified by the comparisons between LIF-IO and LPDOAS-IO presented here. The LIF/LP-DOAS ratio was not constant, however, and was found to be dependent on meteorological conditions and the distribution of macroalgae at the field site, demonstrating that care must be exercised when converting LP-DOAS data to a point source model constraint. At this site, the LP-DOAS instrument detected IO sourced from a southerly direction with greater ability than the LIF instrument. This indicates the advantage of LPDOAS compared to LIF to detect IO when the source is at greater distances or when a larger measurement footprint is required. The combination of point source and spatially averaged measurements improves the ability to interpret halogen chemistry. In the future, a mobile $\mathrm{I}_{2}$ or IO instrument would provide an excellent way to measure the concentration of these species directly at the macroalgae beds, thus providing greater measurement of the spatial gradient of $\mathrm{I}_{2}$ and IO.

Ultra fine particles were found to strongly correlate with IO measured by LIF, providing further evidence that coastal new particle events are due to emission of iodine species from macroalgae via formation pathways involving IO.

A modelling study concludes that at coastal environments such as Roscoff the presence of IO via the exposure of macroalgae has significant impacts on the local $\mathrm{HO}_{\mathrm{x}}$ levels. Under low $\mathrm{NO}_{\mathrm{x}}$ conditions, the presence of $\mathrm{IO}$ increases $\mathrm{OH}$ levels and the oxidative capacity of the atmosphere, but as $\mathrm{NO}_{\mathrm{x}}$ concentrations increase the presence of IO eventually results in a decrease of $\mathrm{OH}$. Iodine was found to decrease the oxidative capacity of the atmosphere at the higher $\mathrm{NO}_{\mathrm{x}}$ concentrations experienced during the campaign. 
Table A2. Halogen chemistry reaction scheme - bimolecular reactions. DMS=dimethyl sulphide.

\begin{tabular}{|c|c|c|}
\hline \multicolumn{3}{|l|}{ Bimolecular reactions } \\
\hline Reaction & Rate coefficient $/ \mathrm{cm}^{3}$ molecule ${ }^{-1} \mathrm{~s}^{-1}$ & Reference \\
\hline $\mathrm{I}_{2}+\mathrm{OH} \rightarrow \mathrm{HOI}+\mathrm{I}$ & $1.8 \times 10^{-10}$ & Sander et al. (2006) \\
\hline $\mathrm{I}_{2}+\mathrm{O}_{3} \rightarrow \mathrm{IO}+\mathrm{I}+\mathrm{O}_{2}$ & $3.8 \times 10^{-18}$ & Saiz-Lopez et al. (2008) \\
\hline $\mathrm{I}_{2}+\mathrm{O}_{3} \rightarrow \mathrm{OIO}+\mathrm{IO}$ & $3.8 \times 10^{-18}$ & Saiz-Lopez et al. (2008) \\
\hline $\mathrm{I}_{2}+\mathrm{NO}_{3} \rightarrow \mathrm{I}+\mathrm{IONO}_{2}$ & $1.5 \times 10^{-12}$ & Atkinson et al. (2007) \\
\hline $\mathrm{I}+\mathrm{O}_{3} \rightarrow \mathrm{IO}+\mathrm{O}_{2}$ & $2.3 \times 10^{-11} \exp (-870 / T)$ & Sander et al. (2006) \\
\hline $\mathrm{I}+\mathrm{HO}_{2} \rightarrow \mathrm{HI}+\mathrm{O}_{2}$ & $1.5 \times 10^{-11} \exp (-1090 / T)$ & Sander et al. (2006) \\
\hline $\mathrm{I}+\mathrm{NO}_{3} \rightarrow \mathrm{IO}+\mathrm{NO}_{2}$ & $4.5 \times 10^{-10}$ & Chambers et al. (1992) \\
\hline $\mathrm{IO}+\mathrm{HO}_{2} \rightarrow \mathrm{HOI}+\mathrm{O}_{2}$ & $1.4 \times 10^{-11} \exp (540 / T)$ & Atkinson et al. (2007) \\
\hline $\mathrm{IO}+\mathrm{NO} \rightarrow \mathrm{I}+\mathrm{NO}_{2}$ & $9.1 \times 10^{-12} \exp (240 / T)$ & Sander et al. (2006) \\
\hline $\mathrm{IO}+\mathrm{IO} \rightarrow 0.38 \mathrm{OIO}+\mathrm{I}$ & $5.4 \times 10^{-11} \exp (180 / T)$ & Atkinson et al. (2007) \\
\hline $\mathrm{IO}+\mathrm{IO} \rightarrow 0.51 \mathrm{I}_{2} \mathrm{O}_{2}$ & $5.4 \times 10^{-11} \exp (180 / T)$ & Atkinson et al. (2007) \\
\hline $\mathrm{IO}+\mathrm{IO} \rightarrow 0.112 \mathrm{I}+\mathrm{O}_{2}$ & $5.4 \times 10^{-11} \exp (180 / T)$ & Atkinson et al. (2007) \\
\hline $\mathrm{IO}+\mathrm{DMS} \rightarrow \mathrm{I}+\mathrm{DMSO}$ & $9.6 \times 10^{-12} \exp (-1816 / T)$ & Gravestock et al. (2005) \\
\hline $\mathrm{IO}+\mathrm{OI} \rightarrow \mathrm{I}_{2} \mathrm{O}_{3}$ & $5 \times 10^{-11}$ & Gomez Martin et al. (2007) \\
\hline $\mathrm{IO}+\mathrm{NO}_{3} \rightarrow \mathrm{OIO}+\mathrm{NO}_{2}$ & $9 \times 10^{-12}$ & Dillon et al. (2008) \\
\hline $\mathrm{OIO}+\mathrm{OIO} \rightarrow \mathrm{I}_{2} \mathrm{O}_{4}$ & $1.2 \times 10^{-10}$ & Gomez Martin et al. (2007) \\
\hline $\mathrm{OIO}+\mathrm{OH} \rightarrow \mathrm{HOIO}_{2}$ & $2.2 \times 10^{-10} \exp (243 / T)$ & Plane et al. (2006) \\
\hline $\mathrm{OIO}+\mathrm{NO} \rightarrow \mathrm{IO}+\mathrm{NO}_{2}$ & $1.1 \times 10^{-12} \exp (542 / T)$ & Plane et al. (2006) \\
\hline $\mathrm{I}_{2} \mathrm{O}_{2}+\mathrm{O}_{3} \rightarrow \mathrm{I}_{2} \mathrm{O}_{3}+\mathrm{O}_{2}$ & $1 \times 10^{-12}$ & Saunders and Plane (2005) \\
\hline $\mathrm{I}_{2} \mathrm{O}_{3}+\mathrm{O}_{3} \rightarrow \mathrm{I}_{2} \mathrm{O}_{4}+\mathrm{O}_{2}$ & $1 \times 10^{-12}$ & Saunders and Plane (2005) \\
\hline $\mathrm{I}_{2} \mathrm{O}_{4}+\mathrm{O}_{3} \rightarrow \mathrm{I}_{2} \mathrm{O}_{5}+\mathrm{O}_{2}$ & $1 \times 10^{-12}$ & Saunders and Plane (2005) \\
\hline $\mathrm{HOI}+\mathrm{OH} \rightarrow \mathrm{IO}+\mathrm{H}_{2} \mathrm{O}$ & $2 \times 10^{-13}$ & Saiz-Lopez et al. (2008) \\
\hline $\mathrm{HI}+\mathrm{OH} \rightarrow \mathrm{I}+\mathrm{H}_{2} \mathrm{O}$ & $3.0 \times 10^{-11}$ & Sander et al. (2006) \\
\hline $\mathrm{Br}_{2}+\mathrm{OH} \rightarrow \mathrm{HOBr}+\mathrm{Br}$ & $2.1 \times 10^{-11} \exp (240 / T)$ & Sander et al. (2006) \\
\hline $\mathrm{Br}+\mathrm{HO}_{2} \rightarrow \mathrm{HBr}+\mathrm{O}_{2}$ & $4.8 \times 10^{-12} \exp (-310 / T)$ & Sander et al. (2006) \\
\hline $\mathrm{Br}+\mathrm{O}_{3} \rightarrow \mathrm{BrO}+\mathrm{O}_{2}$ & $1.7 \times 10^{-11} \exp (-800 / T)$ & Sander et al. (2006) \\
\hline $\mathrm{Br}+\mathrm{HCHO} \rightarrow \mathrm{HBr}+\mathrm{HCO}$ & $1.7 \times 10^{-11} \exp (-800 / T)$ & Sander et al. (2006) \\
\hline $\mathrm{Br}+\mathrm{CH}_{3} \mathrm{CHO} \rightarrow \mathrm{HBr}+\mathrm{CH}_{3} \mathrm{CO}$ & $1.3 \times 10^{-11} \exp (-360 / T)$ & Atkinson et al. (2002) \\
\hline $\mathrm{BrO}+\mathrm{O} \rightarrow \mathrm{Br}+\mathrm{O}_{2}$ & $1.9 \times 10^{-11} \exp (230 / T)$ & Sander et al. (2006) \\
\hline $\mathrm{BrO}+\mathrm{OH} \rightarrow \mathrm{HO}_{2}+\mathrm{Br}$ & $1.7 \times 10^{-11} \exp (250 / T)$ & Sander et al. (2006) \\
\hline $\mathrm{BrO}+\mathrm{HO}_{2} \rightarrow \mathrm{HOBr}+\mathrm{O}_{2}$ & $4.5 \times 10^{-12} \exp (460 / T)$ & Sander et al. (2006) \\
\hline $\mathrm{BrO}+\mathrm{NO} \rightarrow \mathrm{NO}_{2}+\mathrm{Br}$ & $8.8 \times 10^{-12} \exp (260 / T)$ & Sander et al. (2006) \\
\hline $\mathrm{BrO}+\mathrm{BrO} \rightarrow \mathrm{Br}+\mathrm{Br}+\mathrm{O}_{2}$ & $2.4 \times 10^{-12} \exp (40 / T)$ & Sander et al. (2006) \\
\hline $\mathrm{BrO}+\mathrm{BrO} \rightarrow \mathrm{Br}_{2}+\mathrm{O}_{2}$ & $2.8 \times 10^{-14} \exp (860 / T)$ & Sander et al. (2006) \\
\hline $\mathrm{BrO}+\mathrm{IO} \rightarrow 0.3\left(\mathrm{Br}+\mathrm{I}+\mathrm{O}_{2}\right)+0.7(\mathrm{Br}+\mathrm{OIO})$ & $2.5 \times 10^{-11} \exp (260 / T)$ & Sander et al. (2006) \\
\hline $\mathrm{BrO}+\mathrm{I} \rightarrow \mathrm{IO}+\mathrm{Br}$ & $1.2 \times 10^{-11}$ & Sander et al. (2006) \\
\hline $\mathrm{BrO}+\mathrm{DMS} \rightarrow \mathrm{Br}+\mathrm{DMSO}$ & $1.5 \times 10^{-14} \exp (850 / T)$ & Sander et al. (2006) \\
\hline $\mathrm{HOBr}+\mathrm{O} \rightarrow \mathrm{OH}+\mathrm{BrO}$ & $1.2 \times 10^{-10} \exp (-430 / T)$ & Sander et al. (2006) \\
\hline $\mathrm{HBr}+\mathrm{OH} \rightarrow \mathrm{H}_{2} \mathrm{O}+\mathrm{Br}$ & $5.5 \times 10^{-12} \exp (200 / T)$ & Sander et al. (2006) \\
\hline $\mathrm{BrNO}_{3}+\mathrm{I} \rightarrow \mathrm{IBr}+\mathrm{NO}_{3}$ & $2.0 \times 10^{-10}$ & estimated from the rate coefficient of $\mathrm{BrNO}_{3}+\mathrm{Br}$ \\
\hline $\mathrm{BrNO}_{3}+\mathrm{Br} \rightarrow \mathrm{Br}_{2}+\mathrm{NO}_{3}$ & $4.9 \times 10^{-11}$ & Orlando and Tyndall (1996) \\
\hline $\mathrm{BrNO}_{3}+\mathrm{NO} \rightarrow \mathrm{BrNO}+\mathrm{NO}_{3}$ & $3 \times 10^{-19}$ & Orlando and Tyndall (1996) \\
\hline $\mathrm{BrNO}_{3}+\mathrm{BrNO} \rightarrow \mathrm{Br}_{2}+2 \mathrm{NO}_{2}$ & $1 \times 10^{-16}$ & Orlando and Tyndall (1996) \\
\hline
\end{tabular}


Table A3. Halogen chemistry reaction scheme - termolecular reactions.

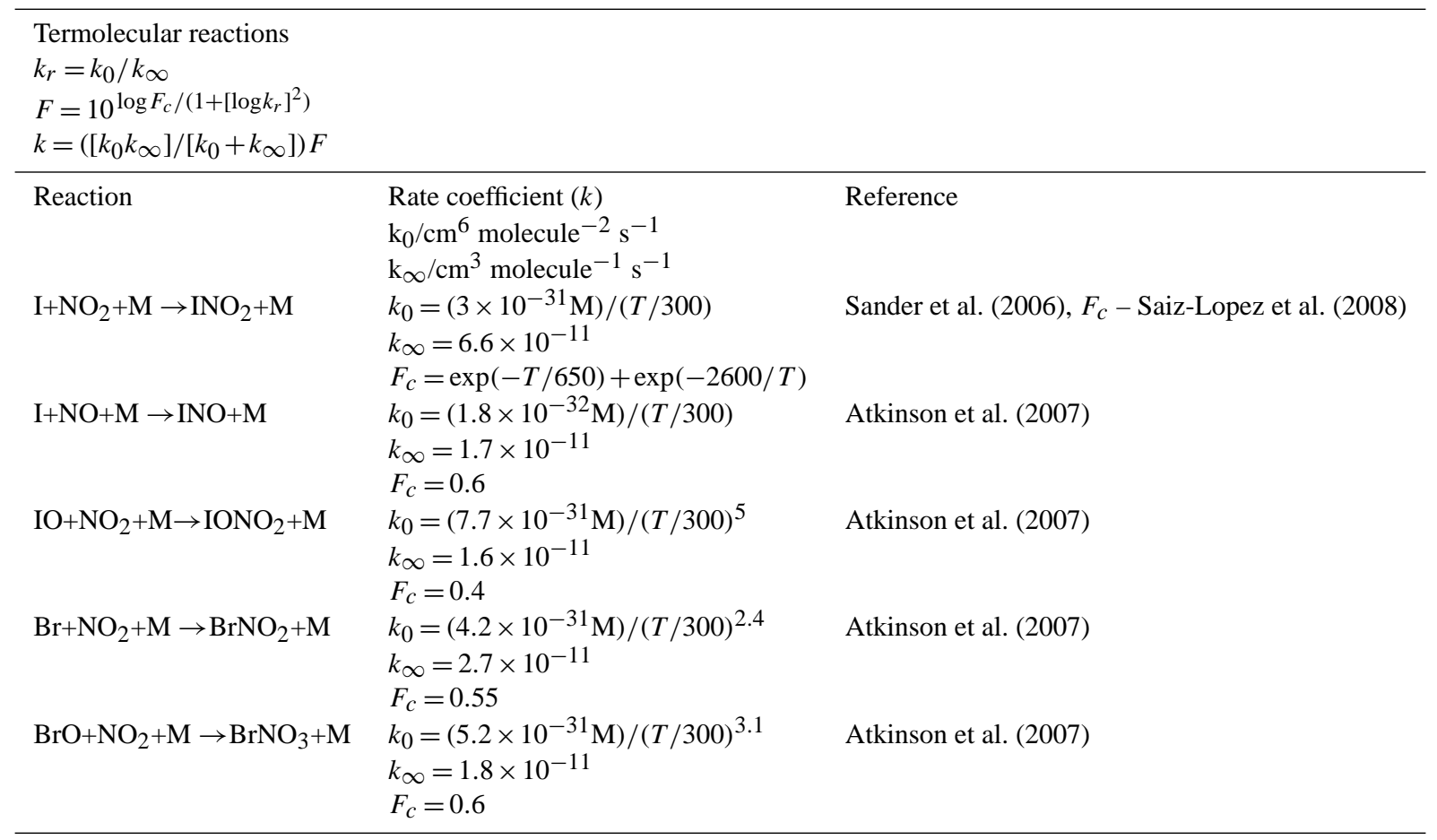

Table A4. Halogen chemistry reaction scheme - photochemical reactions. Citation refers to recommended absorption cross section and quantum yield.

\begin{tabular}{ll}
\hline Halogen Photolysis & \\
\hline Photochemical reactions & Reference \\
\hline $\mathrm{I}_{2} \rightarrow 2 \mathrm{I}$ & Saiz-Lopez et al. (2004) \\
$\mathrm{IO} \rightarrow \mathrm{I}+\mathrm{O}$ & Sander et al. (2006) \\
$\mathrm{OIO} \rightarrow \mathrm{I}+\mathrm{O}_{2}$ & Gomez Martin et al. (2009) \\
$\mathrm{HOI} \rightarrow \mathrm{I}+\mathrm{OH}$ & Sander et al. (2006) \\
$\mathrm{INO} \rightarrow 0.5\left(\mathrm{I}+\mathrm{NO}_{2}\right) / 0.5(\mathrm{IO}+\mathrm{NO})$ & Sander et al. (2006) \\
$\mathrm{IONO}_{2} \rightarrow \mathrm{I}+\mathrm{NO}_{3}$ & Joseph et al. (2007) \\
$\mathrm{CH}_{3} \mathrm{I} \rightarrow \mathrm{CH}_{3}+\mathrm{I}$ & Atkinson et al. (2004) \\
$\mathrm{CH}_{2} \mathrm{I}_{2} \rightarrow \mathrm{CH}_{2}+2 \mathrm{I}$ & Roehl et al. (1997) \\
$\mathrm{CH}_{2} \mathrm{IBr} \rightarrow \mathrm{CH} \mathrm{H}_{2}+\mathrm{I}+\mathrm{Br}$ & Mossinger et al. (1998) \\
$\mathrm{INO} \rightarrow \mathrm{I}+\mathrm{NO}$ & Sander et al. (2006) \\
$\mathrm{Br}_{2} \rightarrow 2 \mathrm{Br}$ & Passchier et al. (1967) \\
$\mathrm{BrO} \rightarrow \mathrm{Br}+\mathrm{O}_{\mathrm{HOBr} \rightarrow \mathrm{Br}+\mathrm{OH}}$ & Atkinson et al. (2007) \\
$\mathrm{BrNO}_{2} \rightarrow \mathrm{Br}+\mathrm{NO}_{2}$ & Atkinson et al. (2007) \\
$\mathrm{BrNO}_{3} \rightarrow \mathrm{Br}+\mathrm{NO}_{3}$ & Atkinson et al. (2007) \\
$\mathrm{IBr} \rightarrow \mathrm{I}+\mathrm{Br}$ & Atkinson et al. (2007) \\
\hline
\end{tabular}

Table A5. Halogen chemistry reaction scheme - loss to aerosol.

\begin{tabular}{lll}
\hline \multicolumn{2}{l}{ Loss to aerosol } & \\
\hline Species & Uptake coefficient & Reference \\
\hline $\mathrm{IO}$ & 0.02 & Saiz-Lopez et al. (2008) \\
$\mathrm{OIO}$ & 1 & Saiz-Lopez et al. (2008) \\
$\mathrm{HI}$ & 0.02 & Saiz-Lopez et al. (2008) \\
$\mathrm{HOI}$ & 0.02 & Saiz-Lopez et al. (2008) \\
$\mathrm{INO}_{2}$ & 0.02 & Saiz-Lopez et al. (2008) \\
$\mathrm{IONO}_{2}$ & 0.02 & Saiz-Lopez et al. (2008) \\
$\mathrm{I}_{2} \mathrm{O}_{5}$ & 0.02 & Saiz-Lopez et al. (2008) \\
$\mathrm{N}_{2} \mathrm{O}_{5}$ & 0.03 & Saiz-Lopez et al. (2008) \\
$\mathrm{NO}_{3}$ & 0.003 & Saiz-Lopez et al. (2008) \\
$\mathrm{OH}$ & $1.2 \times 10^{-5} \exp (1750 / T)$ & Saiz-Lopez et al. (2008) \\
$\mathrm{HO}_{2}$ & $1.4 \times 10^{-8} \exp (3780 / T)$ & Saiz-Lopez et al. (2008) \\
$\mathrm{CH}_{3} \mathrm{O}_{2}$ & 0.004 & Saiz-Lopez et al. (2008) \\
$\mathrm{HNO}_{3}$ & 0.014 & Saiz-Lopez et al. (2008) \\
$\mathrm{NO}_{2}$ & 0.0004 & Jacob (2000) \\
$\mathrm{HOBr}$ & 0.02 & Saiz-Lopez et al. (2008) \\
$\mathrm{HBr}$ & 0.02 & Saiz-Lopez et al. (2008) \\
$\mathrm{BrNO}_{3}$ & 0.02 & Saiz-Lopez et al. (2008) \\
\hline
\end{tabular}


Acknowledgements. The authors would like to thank P. Pontin (Station Biologique de Roscoff, France) for organisational and logistical support prior to and throughout the RHaMBLe-Roscoff field campaign, and for the provision of the raw bathymetry data and seaweed mapping used to produce the macroalgae map. R. Dunk (Crichton Carbon Centre, formerly University of York) is acknowledged for providing the tidal height data. Thanks also to the University of Leeds, School of Chemistry mechanical and electronic workshops for their help in construction of the LIF IO instrument. We thank NERC for the award of studentship to KLF. ASM acknowledges a University of Leeds studentship.

Edited by: W. T. Sturges

\section{References}

Alicke, B., Hebestreit, K., Stutz, J., and Platt, U.: Iodine oxide in the marine boundary layer, Nature, 397, 572-573, 1999.

Allan, B., McFiggans, G., Plane, J., and Coe, H.: Observations of iodine monoxide in the remote marine boundary layer, J. Geophys. Res, 105, 14363-14369, 2000.

Atkinson, R., Baulch, D. L., Cox, R. A., Crowley, J., Hampson, R. F., Kerr, J. A., Rossi, M., and Troe, J.: Summary of evaluated kinetic and photochemical data for atmospheric chemistry, Tech. Rep., 2002.

Atkinson, R., Baulch, D., Cox, R., Crowley, J., Hampson, J. R., Kerr, J., Rossi, M., and Troe, J.: Summary of evaluated kinetic and photochemical data for atmospheric chemistry, IUPAC Subcommittee on Gas Kinetic Data Evaluation for Atmospheric Chemistry, 2004.

Atkinson, R., Baulch, D. L., Cox, R. A., Crowley, J. N., Hampson, R. F., Hynes, R. G., Jenkin, M. E., Rossi, M. J., and Troe, J.: Evaluated kinetic and photochemical data for atmospheric chemistry: Volume III - gas phase reactions of inorganic halogens, Atmos. Chem. Phys., 7, 981-1191, 2007,

http://www.atmos-chem-phys.net/7/981/2007/.

Bloss, W. J., Lee, J. D., Johnson, G. P., Sommariva, R., Heard, D. E., Saiz-Lopez, A., Plane, J. M. C., McFiggans, G., Coe, H., Flynn, M., Williams, P., Rickard, A. R., and Fleming, Z. L.: Impact of halogen monoxide chemistry upon boundary layer $\mathrm{OH}$ and $\mathrm{HO}_{2}$ concentrations at a coastal site, Geophys. Res. Lett., 32, L06814, doi:10.1029/2004GL022084, 2005.

Bloss, W. J., Lee, J. D., Heard, D. E., Salmon, R. A., Bauguitte, S. J.-B., Roscoe, H. K., and Jones, A. E.: Observations of $\mathrm{OH}$ and $\mathrm{HO}_{2}$ radicals in coastal Antarctica, Atmos. Chem. Phys., 7, 4171-4185, 2007,

http://www.atmos-chem-phys.net/7/4171/2007/.

Burkholder, J. B., Curtius, J., Ravishankara, A. R., and Lovejoy, E. R.: Laboratory studies of the homogeneous nucleation of iodine oxides, Atmos. Chem. Phys., 4, 19-34, 2004,

http://www.atmos-chem-phys.net/4/19/2004/.

Cainey, J. M., Keywood, M., Grose, M. R., Krummel, P., Galbally, I. E., Johnston, P., Gillett, R. W., Meyer, M., Fraser, P., Steele, P., Harvey, M., Kreher, K., Stein, T., Ibrahim, O., Ristovski, Z. D., Johnson, G., Fletcher, C. A., Bigg, E. K., and Gras, J. L.: Precursors to Particles (P2P) at Cape Grim 2006: campaign overview, Environ. Chem., 4, 143-150, 2007.

Chambers, R. M., Heard, A. C., and Wayne, R. P.: Inorganic GasPhase Reactions of the Nitrate Radical: $\mathrm{I}_{2}+\mathrm{NO}_{3}$ and $\mathrm{I}+\mathrm{NO}_{3}$, J.
Phys. Chem., 96, 3321-3331, 1992.

Cox, R. A., Bloss, W. J., Jones, R. L., and Rowley, D. M.: OIO and the Atmospheric Cycle of Iodine, Geophys. Res. Lett., 26, 1857-1860, 1999.

Davis, D., Crawford, J., Liu, S., McKeen, S., Bandy, A., Thornton, D., Rowland, F., and Blake, D.: Potential impact of iodine on tropospheric levels of ozone other critical oxidants, J. Geophys. Res., 101, 2135-2147, 1996.

Dillon, T. J., Tucceri, M. E., Sander, R., and Crowley, J. N.: LIF studies of iodine oxide chemistry, Phys. Chem. Chem. Phys., 10, 1540-1554, 2008.

Gilfedder, B. S., Lai, S. C., Petri, M., Biester, H., and Hoffmann, T.: Iodine speciation in rain, snow and aerosols, Atmos. Chem. Phys., 8, 6069-6084, 2008, http://www.atmos-chem-phys.net/8/6069/2008/.

Gomez Martin, J. C., Spietz, P., and Burrows, J. P.: Kinetic and Mechanistic Studies of the $\mathrm{I}_{2} / \mathrm{O}_{3}$ Photochemistry, J. Phys. Chem. A, 111, 306-320, doi:10.1021/jp061186c, 2007.

Gomez Martin, J. C., Ashworth, S. H., Mahajan, A. S., and Plane, J. M. C.: The photochemistry of OIO: laboratory study and atmospheric implications, Geophys. Res. Lett., 36, L09802, doi:10.1029/2009GL037642, 2009.

Gravestock, T., Blitz, M. A., and Heard, D. E.: Kinetics study of the reaction of iodine monoxide radicals with dimethyl sulfide, Phys. Chem. Chem. Phys., 7, 2173-2181, 2005.

Heard, D. E., Read, K. A., Methven, J., Al-Haider, S., Bloss, W. J., Johnson, G. P., Pilling, M. J., Seakins, P. W., Smith, S. C., Sommariva, R., Stanton, J. C., Still, T. J., Ingham, T., Brooks, B., De Leeuw, G., Jackson, A. V., McQuaid, J. B., Morgan, R., Smith, M. H., Carpenter, L. J., Carslaw, N., Hamilton, J., Hopkins, J. R., Lee, J. D., Lewis, A. C., Purvis, R. M., Wevill, D. J., Brough, N., Green, T., Mills, G., Penkett, S. A., Plane, J. M. C., Saiz-Lopez, A., Worton, D., Monks, P. S., Fleming, Z., Rickard, A. R., Alfarra, M. R., Allan, J. D., Bower, K., Coe, H., Cubison, M., Flynn, M., McFiggans, G., Gallagher, M., Norton, E. G., O’Dowd, C. D., Shillito, J., Topping, D., Vaughan, G., Williams, P., Bitter, M., Ball, S. M., Jones, R. L., Povey, I. M., O’Doherty, S., Simmonds, P. G., Allen, A., Kinnersley, R. P., Beddows, D. C. S., Dall'Osto, M., Harrison, R. M., Donovan, R. J., Heal, M. R., Jennings, S. G., Noone, C., and Spain, G.: The North Atlantic Marine Boundary Layer Experiment(NAMBLEX), Overview of the campaign held at Mace Head, Ireland, in summer 2002, Atmos. Chem. Phys., 6, 2241-2272, 2006, http://www.atmos-chem-phys.net/6/2241/2006/.

Hoffmann, T., O'Dowd, C. D., and Seinfeld, J. H.: Iodine oxide homogeneous nucleation: An explanation for coastal new particle formation, Geophys. Res. Lett., 28, 1949-1952, 2001.

Jacob, D. J.: Heterogeneous chemistry and tropospheric ozone, Atmos. Environ., 34, 2131-2159, 2000.

Jenkin, M. E., Saunders, S. M., and Pilling, M. J.: The tropospheric degradation of volatile organic compounds: A protocol for mechanism development, Atmos. Environ., 31, 81-104, 1997.

Jenkin, M. E., Saunders, S. M., Wagner, V., and Pilling, M. J.: Protocol for the development of the Master Chemical Mechanism, MCM v3 (Part B): tropospheric degradation of aromatic volatile organic compounds, Atmos. Chem. Phys., 3, 181-193, 2003, http://www.atmos-chem-phys.net/3/181/2003/.

Jimenez, J. L., Bahreini, R., Cocker III, D. R., Zhuang, H., Varutbangkul, V., Flagan, R. C., Seinfeld, J. H., O’Dowd, C. D., and 
Hoffman, T.: New particle formation from photooxidation of diiodomethane $\left(\mathrm{CH}_{2} \mathrm{I}_{2}\right)$, J. Geophys. Res., 108(D10), 4318, 2003.

Joseph, D. M., Ashworth, S. H., and Plane, J. M. C.: On the photochemistry of $\mathrm{IONO}_{2}$ : aborsption cross section $(240-370 \mathrm{~nm})$ and photolysis product yields at $248 \mathrm{~nm}$, Phys. Chem. Chem. Phys., 9, 5599-5607, 2007.

Kaltsoyannis, N. and Plane, J. M. C.: Quantum chemical calculations on a selection of iodine-containing species (IO, OIO, $\mathrm{INO}_{3}$, $(\mathrm{IO})_{2}, \mathrm{I}_{2} \mathrm{O}_{3}, \mathrm{I}_{2} \mathrm{O}_{4}$, and $\mathrm{I}_{2} \mathrm{O}_{5}$ ) of importance in the atmosphere, Phys. Chem. Chem. Phys., 10, 1723-1733, 2008.

Kanaya, Y., Yokouchi, Y., Matsumoto, J., Nakamura, K., Kato, S., Tanimoto, H., Furutani, H., Toyota, K., and Akimoto, H.: Implications of iodine chemistry for daytime $\mathrm{HO}_{2}$ levels at Rishiri Island, Geophys. Res. Lett., 29, 1212, doi:10.1029/2001GL014061, 2002.

Keene, W. C., Long, M. S., Pszenny, A. A. P., Sander, R., Maben, J. R., Wall, A. J., O'Halloran, T. L., Kerkweg, A., Fischer, E. V., and Schrems, O.: Latitudinal variation in the multiphase chemical processing of inorganic halogens and related species over the eastern North and South Atlantic Oceans, Atmos. Chem. Phys. Discuss., 9, 11889-11950, 2009,

http://www.atmos-chem-phys-discuss.net/9/11889/2009/.

Kulmala, M., Pirjola, L., and Makela, J. M.: Stable sulphate clusters as a source of new atmospheric particles, Nature, 404, 66-69, 2000 .

Langridge, J. M., Ball, S. M., Shillings, A. J. L., and Jones, R. L.: A broadband absorption spectromenter using light emitting diodes for ultrasensitive, in situ trace gas detection, Rev. Sci. Instrum., 79(123), 110-114, 2008.

Leigh, R. J., Corlett, G. K., Friess, U., and Monks, P.: A concurrent multi-axis differential optical absorption spectroscopy system for the measurement of tropospheric nitrogen dioxide, Appl. Optics, 45, 7504-7518, 2006.

Leigh, R. J., Ball, S. M., Whitehead, J., Leblanc, C., Shillings, A. J. L., Mahajan, A. S., Oetjen, H., Dorsey, J. R., Gallagher, M., Jones, R. L., Plane, J. M. C., Potin, P., and McFiggans, G.: Measurements and modelling of molecular iodine emissions, transport and photodestruction in the coastal region around Roscoff, Atmos. Chem. Phys. Discuss., 9, 21165-21198, 2009, http://www.atmos-chem-phys-discuss.net/9/21165/2009/.

Mahajan, A. S., Oetjen, H., Saiz-Lopez, A., Lee, J. D., McFiggans, G. B., and Plane, J. M. C.: Reactive iodine species in a semi-polluted environment, Geophys. Res. Lett., 36, L16803, doi:10.1029/2009GL038018, 2009a.

Mahajan, A. S., Plane, J. M. C., Oetjen, H., Mendes, L., Saunders, R. W., Saiz-Lopez, A., Jones, C. E., Carpenter, L. J., and McFiggans, G. B.: Measurement and modelling of reactive halogen species over the tropical Atlantic Ocean, Atmos. Chem. Phys. Discuss., 9, 24281-24316, 2009b, http://www.atmos-chem-phys-discuss.net/9/24281/2009/.

Makela, J. M., Hoffmann, T., Holzke, C., Vakeva, M., Suni, T., Mattila, T., Aalto, P. P., Tapper, U., Kauppinen, E. I., and O’Dowd, C. D.: Biogenic iodine emissions and identification of endproducts in coastal ultrafine particles during nucleation bursts, J. Geophys. Res., 107(D19), 8110, 2002.

McFiggans, G., Plane, J. M. C., Allan, B. J., Carpenter, L. J., Coe, H., and O'Dowd, C.: A modeling study of iodine chemistry in the marine boundary layer, J. Geophys. Res., 105, 14371-14385, 2000 .
McFiggans, G., Cox, R. A., Mossinger, J. C., Allan, B. J., and Plane, J. M. C.: Active chlorine release from marine aerosol: roles for reactive iodine andnitrogen species, J. Geophys. Res., 107(D15), 4271, doi:10.1029/2001JD000383, 2002.

McFiggans, G., Coe, H., Burgess, R., Allan, J., Cubison, M., Alfarra, M. R., Saunders, R., Saiz-Lopez, A., Plane, J. M. C., Wevill, D., Carpenter, L., Rickard, A. R., and Monks, P. S.: Direct evidence for coastal iodine particles from Laminaria macroalgae - linkage to emissions of molecular iodine, Atmos. Chem. Phys., 4, 701-713, 2004,

http://www.atmos-chem-phys.net/4/701/2004/.

McFiggans, G., Bale, C. S. E., Ball, S. M., Beames, J. M., Bloss, W. J., Carpenter, L. J., Dorsey, J., Dunk, R., Flynn, M. J., Furneaux, K. L., Gallagher, M. W., Heard, D. E., Hollingsworth, A. M., Hornsby, K., Ingham, T., Jones, C. E., Jones, R. L., Kramer, L. J., Langridge, J. M., Leblanc, C., LeCrane, J.-P., Lee, J. D., Leigh, R. J., Longley, I., Mahajan, A. S., Monks, P. S., Oetjen, H., Orr-Ewing, A. J., Plane, J. M. C., Potin, P., Shillings, A. J. L., Thomas, F., von Glasow, R., Wada, R., Whalley, L. K., and Whitehead, J. D.: Iodine-mediated coastal particle formation: an overview of the Reactive Halogens in the Marine Boundary Layer (RHaMBLe) Roscoff coastal study, Atmos. Chem. Phys., 10, 2975-2999, 2010,

http://www.atmos-chem-phys.net/10/2975/2010/.

Mossinger, J. C., Shallcross, D. E., and Cox, R.: UV-VIS absorption cross-sections and atmospheric lifetimes of $\mathrm{CH}_{2} \mathrm{Br}_{2}, \mathrm{CH}_{2} \mathrm{I}_{2}$, and $\mathrm{CH}_{2}$ BrI, J. Chem. Soc. Faraday T., 94, 1391-1396, 1998.

O’Dowd, C., McFiggans, G., Creasey, D. J., Pirjola, L., Hoell, C., Smith, M. H., Allan, B. J., Plane, J. M. C., Heard, D. E., Lee, J. D., Pilling, M. J., and Kulmala, M.: On the photochemical production of new particles in the coastal boundary layer, Geophys. Res. Lett., 26, 1707-1710, 1999.

O’Dowd, C. D., Jimenez, J. L., Bahreini, R., Flagan, R. C., Seinfeld, J. H., Hameri, K., Pirjola, L., Kulmala, M., and Jennings, S. G.: Marine aerosol formation from biogenic emissions, Nature, 417, 632-636, 2002.

Orlando, J. J. and Tyndall, G. S.: Rate Coefficients for the Thermal Decomposition of $\mathrm{BrONO}_{2}$ and the Heat of Formation of BrONO 2 , J. Phys. Chem., 100, 19398-19405, 1996.

Palmer, C. J., Anders, T. L., Carpenter, L. J., Kupper, F. C., and McFiggans, G. B.: Iodine and Halocarbon Response of Laminaria digitata to Oxidative Stress and Links to Atmospheric New Particle Production, Environ. Chem., 2, 282-290, 2005.

Passchier, A., Christian, J., and Gregory, N.: The ultraviolet-visible absorption spectrum of bromine between room temperature and 440 degrees C, J. Phys. Chem., 71, 937-942, 1967.

Pechtl, S., Lovejoy, E. R., Burkholder, J. B., and von Glasow, R.: Modeling the possible role of iodine oxides in atmospheric new particle formation, Atmos. Chem. Phys., 6, 505-523, 2006, http://www.atmos-chem-phys.net/6/505/2006/.

Pechtl, S., Schmitz, G., and von Glasow, R.: Modelling iodide iodate speciation in atmospheric aerosol: Contributions of inorganic and organic iodine chemistry, Atmos. Chem. Phys., 7, 1381-1393, 2007, http://www.atmos-chem-phys.net/7/1381/2007/.

Peters, C., Pechtl, S., Stutz, J., Hebestreit, K., Hönninger, G., Heumann, K. G., Schwarz, A., Winterlik, J., and Platt, U.: Reactive and organic halogen species in three different European coastal environments, Atmos. Chem. Phys., 5, 3357-3375, 2005, 
http://www.atmos-chem-phys.net/5/3357/2005/.

Pirjola, L., O’Dowd, C. D., Yoon, Y. J., and Sellegri, K.: Modelling Iodine Particle Formation and Growth from Seaweed in a Chamber, Environ. Chem., 2, 271-281, 2005.

Plane, J., Joseph, D., Allan, B., Ashworth, S., and Francisco, J.: An Experimental and Theoretical Study of the Reactions OIO+NO and OIO+OH, J. Phys. Chem. A, 110, 93-100, 2006.

Plane, J. M. C. and Saiz Lopez, A.: UV-Visible differential optical absorption spectroscopy (DOAS), chapter 3, in: Analytical Techniques for Atmospheric Measurement, edited by: Heard, D. E., Blackwell Publishing, Oxford, 2006.

Platt, U. and Hönninger, G.: The role of halogen species in the troposphere, Chemosphere, 51, 325-338, 2003.

Ravishankara, A. R.: Heterogeneous and multiphase chemistry in the troposphere, Science, 276, 1058-1065, 1997.

Read, K. A., Mahajan, A. S., Carpenter, L. J., Evans, M. J., Bruno, V. E. F., Heard, D. E., Hopkins, J. R., Lee, J. D., Moller, S. J., Lewis, A. C., Mendes, L., McQuaid, J. B., Oetjen, H., SaizLopez, A., Pilling, M. J., and Plane, J. M. C.: Extensive halogenmediated ozone destruction over the tropical Atlantic Ocean, Nature, 453, 1232-1235, 26 June, 2008.

Roehl, C. M., Burkholder, J. B., Moortgat, G. K., Ravishankara, A. R., and Crutzen, P. J.: Temperature dependence of UV absorption cross sections and atmospheric implications of several alkyl iodides, J. Geophys. Res.-Atmos., 102, 12819-12829, 1997.

Saiz-Lopez, A. and Plane, J. M. C.: Novel iodine chemistry in the marine boundary layer, Geophys. Res. Letts., 31, 19215-19218, 2004.

Saiz-Lopez, A., Saunders, R. W., Joseph, D. M., Ashworth, S. H., and Plane, J. M. C.: Absolute absorption cross-section and photolysis rate of $\mathrm{I}_{2}$, Atmos. Chem. Phys., 4, 1443-1450, 2004, http://www.atmos-chem-phys.net/4/1443/2004/.

Saiz-Lopez, A., Plane, J. M. C., McFiggans, G., Williams, P. I., Ball, S. M., Bitter, M., Jones, R. L., Hongwei, C., and Hoffmann, T.: Modelling molecular iodine emissions in a coastal marine environment: the link to new particle formation, Atmos. Chem. Phys., 6, 883-895, 2006,

http://www.atmos-chem-phys.net/6/883/2006/.

Saiz-Lopez, A., Shillito, J. A., Coe, H., and Plane, J. M. C.: Measurements and modelling of $\mathrm{I}_{2}, \mathrm{IO}, \mathrm{OIO}, \mathrm{BrO}$ and $\mathrm{NO}_{3}$ in the mid-latitude marine boundary layer, Atmos. Chem. Phys., 6, 1513-1528, 2006,

http://www.atmos-chem-phys.net/6/1513/2006/.

Saiz-Lopez, A., Plane, J. M. C., Mahajan, A. S., Anderson, P. S., Bauguitte, S. J.-B., Jones, A. E., Roscoe, H. K., Salmon, R. A., Bloss, W. J., Lee, J. D., and Heard, D. E.: On the vertical distribution of boundary layer halogens over coastal Antarctica: implications for $\mathrm{O}_{3}, \mathrm{HO}_{\mathrm{x}}, \mathrm{NO}_{\mathrm{x}}$ and the $\mathrm{Hg}$ lifetime, Atmos. Chem. Phys., 8, 887-900, 2008,

http://www.atmos-chem-phys.net/8/887/2008/.

Sander, S. P., Friedl, R. R., Golden, D. M., Kurylo, M. J., Moortgat, C. K., Keller-Rudek, H., Wine, P. H., Ravishankara, A. R., Kolb, C. E., Molina, M. J., Finlayson-Pitts, B. J., Huie, R. E., and Orkin, V. L.: Chemical kinetics and photochemical data for use in atmospheric Studies, Evaluation number 15, NASA Jet Propulsion Laboratory, Publication 062, 2006.

Saunders, R. W. and Plane, J. M. C.: Formation Pathways and Composition of Iodine Oxide Ultra-Fine Particles, Environ. Chem., 2, 299-303, 2005.
Saunders, S. M., Jenkin, M. E., Derwent, R. G., and Pilling, M. J.: Protocol for the development of the Master Chemical Mechanism, MCM v3 (Part A): tropospheric degradation of nonaromatic volatile organic compounds, Atmos. Chem. Phys., 3, 161-180, 2003,

http://www.atmos-chem-phys.net/3/161/2003/.

Sellegri, K., Yoon, Y. J., Jennings, S. G., O’Dowd, C. D., Pirjola, L., Cautenet, S., Chen, H., and Hoffmann, T.: Quantification of Coastal New ultra-fine Particle Formation from In situ and Chamber Measurements during the BIOFLUX campaign, Environ. Chem., 2, 260-270, 2005.

Sommariva, R., Bloss, W. J., Brough, N., Carslaw, N., Flynn, M., Haggerstone, A.-L., Heard, D. E., Hopkins, J. R., Lee, J. D., Lewis, A. C., McFiggans, G., Monks, P. S., Penkett, S. A., Pilling, M. J., Plane, J. M. C., Read, K. A., Saiz-Lopez, A., Rickard, A. R., and Williams, P. I.: $\mathrm{OH}$ and $\mathrm{HO}_{2}$ chemistry during NAMBLEX: roles of oxygenates, halogen oxides and heterogeneous uptake, Atmos. Chem. Phys., 6, 1135-1153, 2006, http://www.atmos-chem-phys.net/6/1135/2006/.

Stutz, J., Hebestreit, K., Alicke, B., and Platt, U.: Chemistry of Halogen Oxides in the tropsphere: Comparison of Model Calculations with Recent Field Data, J. Atmos. Chem., 34, 65-85, 1999.

Stutz, J., Pikelnaya, O., Hurlock, S. C., Trick, S., Pechtl, S., and von Glasow, R.: Daytime OIO in the Gulf of Maine, Geophys. Res. Lett., 34, L22816, doi:10.1029/2007GL031332, 2007.

Vogt, R., Crutzen, P. J., and Sander, R.: A mechanism for halogen release from sea-salt aerosol in the remote marineboundary layer, Nature, 383, 327-330, 1996.

Vogt, R., Sander, R., von Glasow, R., and Crutzen, P. J.: Iodine Chemistry and its Role in Halogen Activation and Ozone Loss in the Marine Boundary Layer: A Model Study, J. Atmos. Chem., 32, 375-395, 1999.

von Glasow, R. and Crutzen, P. J.: Treatise On Geochemistry: 4.02 Tropspheric Halogen Chemistry, Elsevier, iSBN (set): 0-08043751-6, 2007.

Wada, R., Beames, J. M., and Orr-Ewing, A. J.: Measurement of IO radical concentrations in the marine boundary layer using a cavity ring-down spectrometer, J. Atmos. Chem., 58, 69-87, 2007.

Whalley, L. K., Furneaux, K. L., Gravestock, T., Atkinson, H. M., Bale, C. S. E., Ingham, T., Bloss, W. J., and Heard, D. E.: Detection of Iodine Monoxide Radicals in the Marine Boundary Layer using Laser Induced Fluorescence Spectroscopy, J. Atmos. Chem., 58, 19-39, 2007.

Whalley, L. K., Furneaux, K. L., Goddard, A., Lee, J. D., Mahajan, A., Oetjen, H., Read, K. A., Kaaden, N., Carpenter, L. J., Lewis, A. C., Plane, J. M. C., Saltzman, E. S., Wiedensohler, A., and Heard, D. E.: The chemistry of $\mathrm{OH}$ and $\mathrm{HO}_{2}$ radicals in the boundary layer over the tropical Atlantic Ocean, Atmos. Chem. Phys., 10, 1555-1576, 2010,

http://www.atmos-chem-phys.net/10/1555/2010/.

Whitehead, J. D., McFiggans, G. B., Gallagher, M. W., and Flynn, M. J.: Direct linkage between tidally driven coastal ozone deposition fluxes, particle emission fluxes and subsequent CCN formation, Geophys. Res. Lett., 105, L04806, doi:doi:10.1029/2008GL035969, 2009. 